\title{
Androgen receptor signaling in castration-resistant prostate cancer: a lesson in persistence
}

\author{
Isabel Coutinho1,2, Tanya K Day1,2, Wayne D Tilley1,2 and Luke A Selth',2 \\ 'Dame Roma Mitchell Cancer Research Laboratories, School of Medicine, The University of Adelaide, \\ Adelaide, South Australia, Australia \\ 2Freemasons Foundation Centre for Men's Health, School of Medicine, The University of Adelaide, \\ Adelaide, South Australia, Australia
}

Correspondence should be addressed to L A Selth

Email

luke.selth@adelaide.edu.au

\begin{abstract}
The androgen receptor (AR) signaling axis drives all stages of prostate cancer, including the lethal, drug-resistant form of the disease termed castration-resistant prostate cancer (CRPC), which arises after failure of androgen deprivation therapy (ADT). Persistent AR activity in spite of ADT and the second-generation AR-targeting agents enzalutamide and abiraterone is achieved in many cases by direct alterations to the AR signaling axis. Herein, we provide a detailed description of how such alterations contribute to the development and progression of CRPC. Aspects of this broad and ever-evolving field specifically addressed in this review include: the etiology and significance of increased $A R$ expression; the frequency and role of gain-of-function mutations in the $A R$ gene; the function of constitutively active, truncated forms of the AR termed AR variants and the clinical relevance of alterations to the activity and expression of AR coregulators. Additionally, we examine the novel therapeutic strategies to inhibit these classes of therapy resistance mechanisms, with an emphasis on emerging agents that act in a manner distinct from the current ligand-centric approaches. Throughout, we discuss how the central role of $A R$ in prostate cancer and the constant evolution of the AR signaling axis during disease progression represent archetypes of two key concepts in oncology, oncogene addiction and therapy-mediated selection pressure.
\end{abstract}

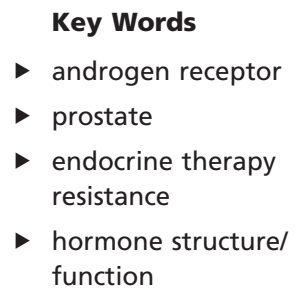

Endocrine-Related Cancer (2016) 23, T179-T197

\section{Introduction}

Prostate cancer (PCa) is the second most commonly diagnosed cancer and a leading cause of cancer-related death in men worldwide (Ferlay et al. 2015). Indeed, in the USA alone, 180,890 new PCa cases are expected to be diagnosed in 2016 (Siegel et al. 2016). Given its critical role in the normal prostate, it is perhaps not surprising that the AR signaling axis is critical for PCa genesis and all subsequent phases of disease progression. This biology underpins the use of androgen deprivation therapy (ADT), a term used to describe hormonal manipulations aimed at reducing androgen levels and/or blocking AR activity, as the mainstay treatment for locally advanced or metastatic disease. Although ADT is initially successful in almost all men, development of resistance is inevitable, normally occurring within a period of 2-3 years. The resultant form of the disease, termed as castration-resistant prostate cancer (CRPC), is incurable and lethal (Scher et al. 2004, Thoreson et al. 2014).

Given the efficacy of ADT in suppressing circulating testosterone levels, it was believed that CRPC was

This paper is part of a thematic review section on hormone-dependent cancers. The Guest Editor for this section was Wayne Tilley 
an AR-independent pathology, leading to its early designations as 'hormone-refractory' or 'androgenindependent' PCa. However, a substantial body of work over the past $\sim 20$ years has demonstrated that the majority of CRPC cases remain dependent on the AR signaling axis. One of the first clues to this concept was the observation of $A R$ gene amplification in over 30\% CRPC of patients after hormonal therapy (Visakorpi et al. 1995). Another early indicator of the relevance of AR in CRPC came from the detection of AR gain-offunction point mutations that were associated with rapid failure of endocrine therapy (Tilley et al. 1996). Subsequently, an elegant study from the Sawyers group showed that reactivation of AR signaling is sufficient and necessary to trigger the CRPC phenotype (Chen et al. 2004). These revelations led to the development of new and more efficacious AR-targeting agents, the AR antagonist enzalutamide and the androgen synthesis inhibitor abiraterone, which provided survival benefits for men with CRPC and definitively proved an ongoing dependence on AR signaling in this disease setting (de Bono et al. 2011, Scher et al. 2012, Ryan et al. 2013, Beer et al. 2014).

Although this review is focused on oncogenic functions of $\mathrm{AR}$ in the prostate, the requirement for AR signaling in normal physiology bears consideration, especially given the widespread use of ADT. AR is almost ubiquitously expressed in the tissues of both males and females, enabling it to mediate a plethora of vital regulatory functions (Lee \& Chang 2003, De Gendt \& Verhoeven 2012). For example, AR is important for the acquisition and maintenance of bone mass by suppressing and stimulating the apoptosis of osteoblasts and osteoclasts, respectively (Mohamad et al. 2016). In the muscle, the AR signaling axis is critical for muscle growth, development and regeneration (Velders \& Diel 2013). AR also influences brain biology and function, and its role in promoting neuron health and growth possibly underlies the link between ADT and dementia (Nead et al. 2016). In females, among other functions, AR is required for normal fertility (De Gendt \& Verhoeven 2012) and plays an important antiproliferative role in the breast (Hickey et al. 2012). The critical reproductive and non-reproductive functions of AR outlined previously are manifested by the adverse side effects associated with ADT, which include sexual dysfunction, decreased lean body mass and strength, osteoporosis, increased cardiovascular disease and cognitive decline (for a detailed review, see Ahmadi \& Daneshmand 2013).

\section{Mechanisms of persistent AR signaling activity in CRPC}

As the major driver of CRPC, there is a critical need to better understand how AR signaling persists in a castration environment. The advent of the omics era, and resultant integrative genomic analyses of metastatic samples, has further highlighted the extent and frequency of AR pathway alterations in CRPC that may contribute to inappropriate activation or reactivation of this pathway (Grasso et al. 2012, Beltran et al. 2013, Azad et al. 2015, Robinson et al. 2015, Lallous et al. 2016). Although these alterations have been the subject of other recent excellent articles (for example Penning 2014, Joshi et al. 2015, Wyatt \& Gleave 2015), this review will specifically focus on ADT-resistance mechanisms driven by direct structural changes to the AR and altered interplay between the AR and its coregulators. Finally, we will summarize the recent progress into the development of novel therapeutic strategies to target these specific resistance mechanisms.

\section{ADT-resistance mechanisms driven by direct structural changes to the AR}

AR overexpression Increased expression of $A R$ is one of the most frequent alterations observed in CRPC (Grasso et al. 2012, Beltran et al. 2013, Robinson et al. 2015) and has been consistently associated with the development of resistance to anti-androgens (Chen et al. 2004, Kawata et al. 2010). Elevated AR hypersensitizes cancer cells to castrate levels of androgens (Visakorpi et al. 1995, Koivisto et al. 1997, Kawata et al. 2010), mediates antagonistagonist switching (Chen et al. 2004) and can promote resistance to AR-targeting agents (Carreira et al. 2014).

Increased AR expression in CRPC is often mediated by $A R$ gene amplification. Pre-treated CRPC tumors exhibit $A R$ amplification rates of $17-57 \%$, depending on the therapy (Grasso et al. 2012, Beltran et al. 2013, Robinson et al. 2015, Kumar et al. 2016). This is in contrast to treatment-naïve tumors, in which copy number gain is rarely detected (Visakorpi et al. 1995, Koivisto et al. 1997, Carreira et al. 2014, Cancer Genome Atlas Research 2015, Kumar et al. 2016). AR gene amplification has also been detected in circulating tumor cells (CTCs) and cell-free circulating tumor DNA (ctDNA) from patients with CRPC (Antonarakis et al. 2014, Carreira et al. 2014, Azad et al. 2015).

Although $A R$ amplification is frequent in CRPC and an important driver of therapy resistance, AR levels can be increased irrespective of gene copy number status

Published by Bioscientifica Ltd 


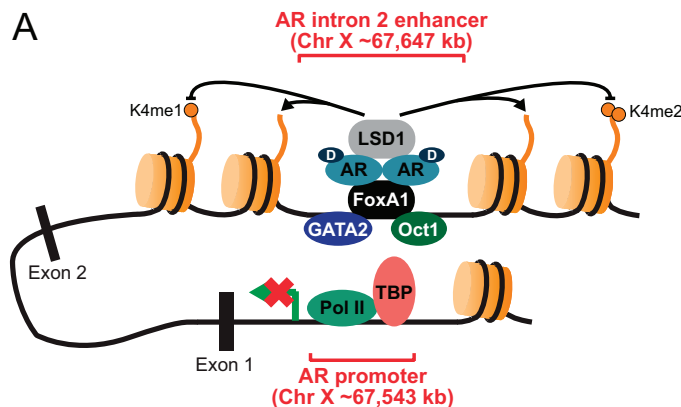

Androgen-replete environment = weak intron 2 enhancer activity = low $A R$ gene transcription

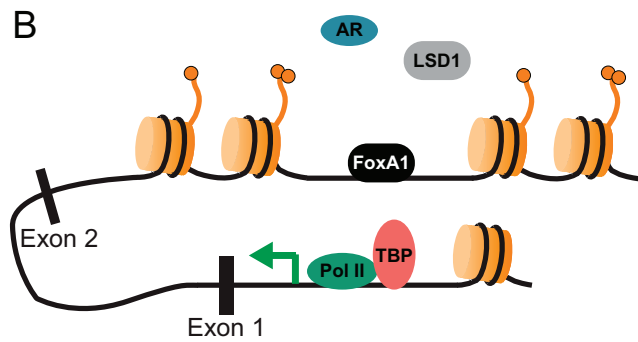

Low androgen environment (i.e. ADT) = strong intron 2 enhancer activity $=$ high $A R$ gene transcription

\begin{abstract}
Figure 1
Model for negative feedback loop mediated by AR (AR autoregulation). (A) Recruitment of ligand-bound $A R$ by FoxA1 to an enhancer in intron 2 of the $A R$ gene results in lysine-specific histone demethylase 1 (LSD1)-mediated demethylation of mono- and di-methylated lysine 4 (K4me1 and K4me2, respectively) on histone $\mathrm{H} 3$ (LSD1 also demethylates K9 at this loci). Formation of this repressive chromatin environment at the intron 2 enhancer, which also involves the transcription factors GATA2 and Oct1, directly suppresses $A R$ gene transcription via chromatin looping back to the promoter. Chromosome coordinates correspond to hg38 assembly. (B) In a low androgen environment, such as occurs during androgen deprivation therapy (ADT), intron 2 enhancer activity is no longer suppressed by ligand-bound AR and LSD1, resulting in increased $A R$ gene transcription. D, DHT; Me, methyl; Me2, dimethyl; Pol II, RNA polymerase II; TBP, TATA-binding protein. This model is based primarily on data from Cai et al. (2011).
\end{abstract}

through transcriptional upregulation. Importantly, a direct mechanism underlying ADT-driven upregulation of the $A R$ gene has been elucidated: liganded AR negatively regulates its own expression by binding to a site in the second intron of the $A R$ gene, and this repression is relieved by AR-targeted therapy (Cai et al. 2011) (Fig. 1). More recently, Spratt and coworkers demonstrated that radiotherapy can also induce $A R$ gene transcription, a response correlated with increased cancer cell survival in vitro and decreased time to disease progression in vivo (Spratt et al. 2015).

AR gene mutations In CRPC, $A R$ mutations have been reported to occur at a frequency of 5-30\% in pretreated tumors (Taplin et al. 1999, Wallen et al. 1999, Grasso et al. 2012, Beltran et al. 2013, Robinson et al. 2015, Kumar et al. 2016), CTCs (Jiang et al. 2010) and ctDNA (Azad et al. 2015, Lallous et al. 2016, Wyatt et al. 2016). Although infrequent, $A R$ mutations have also been detected in primary PCa prior to ADT or arising during treatment, and there is evidence that therapy-mediated selection of such mutations can underlie resistance in some patients (Tilley et al. 1996, Taplin et al. 1999, Thompson et al. 2003, Steinkamp et al. 2009, Carreira et al. 2014, Cancer Genome Atlas Research 2015, Chen et al. 2015). Most AR mutations cluster in domains responsible for ligand-binding (the AR ligand-binding domain, referred to as AR-LBD) or transactivation activity (the AR N-terminal domain, referred to as AR-NTD).
Mutations detected recurrently ( $>1$ sample) in $\mathrm{PCa}$ are listed in Table 1, whereas a comprehensive list of PCaassociated $A R$ mutations and their proposed functions is presented in Supplementary Table 1, see section on supplementary data given at the end of this article. Most mutations identified in CRPC cluster in the AR-LBD. These alterations have been reported to facilitate AR signaling in CRPC by conferring: (i) ligand promiscuity, thereby allowing AR to be activated even in the presence of low/ absent levels of androgens and (ii) agonist properties to AR antagonists (Supplementary Table 1). Recurrently occurring LBD missense mutations in CRPC are $\mathrm{L} 702 \mathrm{H}$, W742C, H875Y and T878A (Grasso et al. 2012, Robinson et al. 2015, Lallous et al. 2016). With the exception of W742C, these AR mutants are represented in commonly used PCa cell lines (T878A in LNCaP, C42B and MDAPCa-2B; L702H in MDA-MB-2B and H875Y in 22Rv1 and CWR-R1), which has facilitated our understanding of their function. The T878A mutant, first identified in the LNCaP cell line (Veldscholte et al. 1990), is the archetypal promiscuous receptor, being activated by progesterone, estrogen and glucocorticoids (Veldscholte et al. 1990, Berrevoets et al. 1993, Suzuki et al. 1996, Culig et al. 1999, Zhao et al. 2000, Steketee et al. 2002, Chen et al. 2015, Lallous et al. 2016). H875Y and L702H also broaden ligand specificity by enabling AR activation by glucocorticoids (Suzuki et al. 1993, Taplin et al. 1995, Zhao et al. 2000, Steketee et al. 2002). Importantly, mutations conferring ligand promiscuity not only can facilitate persistent AR signaling in the castrate environment but

Published by Bioscientifica Ltd. 
Table 1 Recurrent prostate cancer-associated AR missense mutations.

\begin{tabular}{|c|c|c|c|c|c|c|c|c|c|c|c|c|c|c|}
\hline \multirow[b]{2}{*}{ Treatment } & \multirow[b]{2}{*}{ Stage of disease } & \multirow[b]{2}{*}{ Np } & \multirow[b]{2}{*}{ Ns } & \multicolumn{11}{|c|}{ Mutations per sample } \\
\hline & & & & T878A & H875Y & $\mathrm{L} 702 \mathrm{H}$ & $\Delta \mathrm{Q} 86$ & W742C & Q58L & M896V & E213E & Q868* & T878S & $\mathrm{T} 229 \mathrm{C}$ \\
\hline \multirow[t]{14}{*}{ CRPC } & Metastatic & 150 & 150 & 7 & 4 & 7 & & 2 & 1 & & & & 1 & \\
\hline & & 63 & 176 & & 6 & 1 & & 1 & & & & & & \\
\hline & & 62 & 65 & 5 & 9 & & & & & 3 & & & & \\
\hline & & 51 & 70 & & 1 & 3 & & 2 & & & & & & \\
\hline & & 50 & & 3 & 2 & 1 & & & & & & & & \\
\hline & & 48 & 48 & 1 & & & & 1 & & & & & & \\
\hline & & 33 & 33 & 6 & & & & & & & & & 1 & \\
\hline & & 24 & & 6 & & & & & & & & & & \\
\hline & & 22 & 22 & 3 & & & & & & & & & & \\
\hline & & 10 & 10 & 1 & 1 & & & & & & & & 1 & \\
\hline & & 8 & 8 & & & & 5 & & 4 & & 1 & 1 & & 2 \\
\hline & & 8 & 8 & 1 & & & & & & & & & & \\
\hline & & 7 & 7 & & & & & & & & & & & \\
\hline & Localized & 8 & 8 & & & 1 & & & & & & & & \\
\hline \multirow[t]{5}{*}{ Hormone-naïve } & Metastatic & 38 & 38 & & & & & & & & & 1 & & \\
\hline & & 3 & 3 & & & & 2 & & 1 & & & 1 & & \\
\hline & Localized & 499 & & & & & & & 1 & & & & & \\
\hline & & 26 & 26 & & & & & & & & & & & \\
\hline & & 23 & & & & & & & & & & & & \\
\hline \multirow[t]{3}{*}{ Non-specified } & Metastatic & 37 & & 2 & 1 & & & 1 & & & & & & \\
\hline & & 1 & 1 & & & & & & & & & & & \\
\hline & Localized & 67 & 67 & & & & & & & 1 & 2 & & & \\
\hline
\end{tabular}

$\mathrm{AR}$, androgen receptor; CRPC, castration-resistant prostate cancer; $N p$, number of patients enrolled; $N s$, number of samples.

also can result in qualitative changes to the receptor. For example, it has been shown that non-canonical ligands activate specific subsets of genes with relevance to prostate cell proliferation (Brooke et al. 2008, Zaman et al. 2014). Moreover, proteomic and targeted analysis of AR-associated factors revealed that H875Y, T878A and T878S recruit distinct coactivators in response to different ligands (Brooke et al. 2008, Zaman et al. 2014). The T878A mutation also facilitates the interaction with the coactivator steroid receptor coactivator (SRC) 1 and weakens the interaction with the co-repressor NCOR1 (Berrevoets et al. 2004).

The other major phenotypic output of common LBD mutations is antagonist-agonist switching (Supplementary Table 1), which likely explains the withdrawal syndrome observed after cessation of firstgeneration antagonists seen in 15-30\% of patients (Small et al. 2004). T878A confers agonist properties to flutamide and nilutamide, $\mathrm{H} 875 \mathrm{Y}$ to nilutamide and $\mathrm{W} 742 \mathrm{C} / \mathrm{L}$ to bicalutamide (Veldscholte et al. 1990, Suzuki et al. 1996, Tan et al. 1997, Hara et al. 2003, Azad et al. 2015, O'Neill et al. 2015, Lallous et al. 2016). Interestingly, O'Neill and coworkers recently demonstrated that T878A inhibited bicalutamide-activated W742L ( $\mathrm{O}^{\prime}$ Neill et al. 2015) in what may represent the first evidence of antagonism arising from the heterodimerization of distinct AR mutants. Another mutation that can confer antagonist-agonist switching is $\mathrm{F} 877 \mathrm{~L}$, which was found to be activated by enzalutamide in cell lines (Balbas et al. 2013, Joseph et al. 2013, Korpal et al. 2013). Although this alteration was identified in circulating DNA from a small proportion of CRPC patients who were progressing on enzalutamide or ARN-509 (Joseph et al. 2013, Azad et al. 2015), F877L was not detected in a recent study of 150 CRPC metastases, $48 \%$ of which were pre-treated with enzalutamide, suggesting that it may not be a key resistance mechanism (Robinson et al. 2015).

Mutations in the AR-NTD, which account for about a third of all mutations described in AR (Steinkamp et al. 2009) (Supplementary Table 1), usually cause alterations that facilitate AR transactivation activity, such as altered recruitment of coactivators and other components of the transcriptional machinery, increased N/C interaction, increased response to $5 \alpha$-dihydrotestosterone (DHT) activation and enhanced protein stability and nuclear retention (Tilley et al. 1996, Buchanan et al. 2004, Chen et al. 2005, Callewaert et al. 2006, Steinkamp et al. 2009).

Altogether, there is overwhelming evidence that $A R$ mutation represents a key mechanism underlying persistent AR signaling in CRPC. Therefore, monitoring

Published by Bioscientifica Ltd. 

\begin{tabular}{lllllllllllll}
\hline A253V W435L T440P & G456S & G457D & R485C & T498I & V509L & C620Y & V716M & V731M & R787* & S889G
\end{tabular}

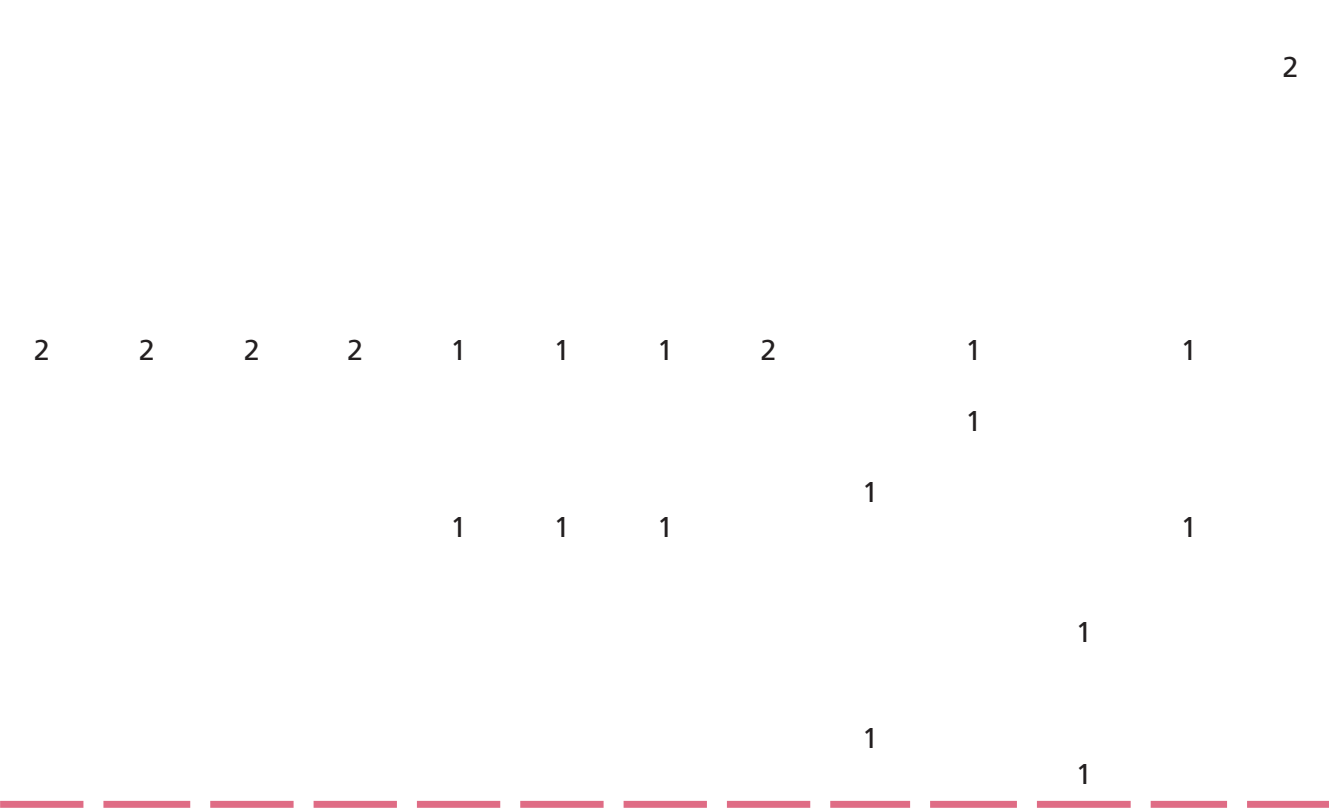

Study

Robinson et al. (2015) Kumar et al. (2016)

Lallous et al. (2016)

Beltran et al. (2016)

Grasso et al. (2012)

Taplin et al. (2003)

Taplin et al. (1999)

Gaddipati et al. (1994)

Suzuki et al. (1996)

Taplin et al. (1995)

Steinkamp et al. (2009)

Suzuki et al. (1993)

Culig et al. (1993)

Suzuki et al. (1993)

Marcelli et al. (2000)

Steinkamp et al. (2009)

Cancer Genome Atlas

Research Network (2015)

Newmark et al. (1992)

Elo et al. (1995)

Taylor et al. (2010)

Nazareth et al. (1999)

Sanchez et al. (2006) the emergence of $A R$ mutations in real time could guide therapy selection, especially in light of the observations that individual mutations do not appear to confer resistance to all AR antagonists (Lallous et al. 2016). In this respect, the emerging capacity to rapidly characterize ctDNA represents an exciting prospect (Carreira et al. 2014, Azad et al. 2015). Additionally, a better understanding of the molecular function of mutant ARs is required to achieve maximal patient benefit. The field has traditionally been limited by a scarcity of CRPC models for studying AR mutant function, but new models derived from patient metastases and CTCs, such as patient-derived xenografts and organoids, are emerging (Gao et al. 2014, Lin et al. 2014, Alsop et al. 2016). As these models encompass the diversity of disease and AR alterations, they are likely to have a profound impact on our knowledge of aberrant AR signaling.

AR splice variants The addiction of prostate cancer cells to AR, manifested by extreme pressure to maintain AR expression and activity, is also associated with the emergence of truncated forms of the receptor. Many of these AR variants (AR-Vs) lack all or part of the transcript encoding the AR-LBD and can be divided into two main classes: those that incorporate a cryptic exon or those arising from exon skipping. Rapid, reversible induction of AR-V expression can be achieved by alternative splicing (Watson et al. 2010, Hu et al. 2012, Gillis et al. 2013, Liu et al. 2013, Yu et al. 2014b), whereas genomic rearrangements within the $A R$ gene can mediate a fully androgen-independent phenotype through a mechanism of switching AR expression from full-length $\mathrm{AR}$ to ARv567es (Nyquist et al. 2013).

$A R-V$ mRNAs have been identified in prostate cancer cell lines, xenografts, mouse models and, most importantly, patient specimens (Dehm et al. 2008, Guo et al. 2009, Hu et al. 2009, Sun et al. 2010, Watson et al. 2010, Hornberg et al. 2011, McGrath et al. 2013, Robinson et al. 2015) (Table 2). The most recent genomic data, based on the detection of unique exon junctions in RNAseq data, estimates that at least 12 distinct $A R-V$ mRNA species are detectable in primary PCa (Cancer Genome Atlas Research 2015) and 23 in mCRPC (Robinson et al. 2015) (for a comprehensive summary of the AR splicing landscape, Supplementary Table 2). The best characterized AR-Vs are AR-V7 and ARv567es, which are discussed in more detail below. The structural properties of AR-Vs, namely, the lack of an intact LBD, theoretically confer ligand-independent activity. However, this concept has only been proven for a subset of AR-Vs (Supplementary Table 2).

Published by Bioscientifica Ltd. 
Table 2 The landscape of AR variants in clinical prostate cancer.

\begin{tabular}{|c|c|c|c|c|c|}
\hline & Name & Exon structure & $\begin{array}{l}\text { Distinguishing } \\
\text { exon junction }\end{array}$ & $\begin{array}{l}\text { Transcriptional } \\
\text { activity }\end{array}$ & Detected in disease stage \\
\hline \multirow{9}{*}{$\begin{array}{l}\text { Inclusion of } \\
\text { non-canonical } \\
\text { exon }\end{array}$} & AR-V1 & 1/2/3/CE1 & 3/CE1 & $\begin{array}{l}\text { Depends on cell } \\
\text { context }\end{array}$ & $\begin{array}{l}\text { Benign, hormone-naïve and CRPC; primary and } \\
\text { metastases (higher in CRPC and metastases) }\end{array}$ \\
\hline & AR-V3 & 1/2/CE4 & 2/CE4 & Constitutive & $\begin{array}{l}\text { Increased levels castrated vs non-treated } \\
\text { xenografts; peritumoral, benign, primary } \\
\text { tumor and mCRPC }\end{array}$ \\
\hline & AR-V5 & 1/2/3/CE2 & 3/CE2 & Unknown & Primary tumor and mCRPC \\
\hline & AR-V6 & 1/2/3/CE2 & 3/CE2' & Unknown & Primary tumor and mCRPC \\
\hline & AR-V7 & 1/2/3/CE3 & 3/CE3 & Constitutive & $\begin{array}{l}\text { Benign, hormone-naïve and CRPC; primary and } \\
\text { metastases (higher in CRPC and metastases) }\end{array}$ \\
\hline & AR-V8 & $1 / 2 / 3 / 13$ & $3 / 13$ & Unknown & Primary tumor and $m C R P C$ \\
\hline & AR-V9 & 1/2/3/CE5 & 3/CE5 & $\begin{array}{l}\text { Depends on cell } \\
\text { context }\end{array}$ & $\begin{array}{l}\text { Benign, hormone-naïve and CRPC; primary and } \\
\text { metastases (higher in CRPC and metastases) }\end{array}$ \\
\hline & AR8 & $1 / 12 / 3$ & $12 / 3$ & $\begin{array}{l}\text { Increases } \\
\text { phosphorylation } \\
\text { of AR-FL }\end{array}$ & Benign, malignant \\
\hline & AR23 & $1 / 2 / 12 / 3 / 4 / 5 / 6 / 7 / 8$ & $2 / 12,12 / 3$ & Ligand-stimulated & Peritumoral, primary tumor and mCRPC \\
\hline \multirow[t]{12}{*}{ Exon skipping } & ARv567es & $1 / 2 / 3 / 4 / 8$ & $4 / 8$ & Constitutive & $\begin{array}{l}\text { Benign, hormone-naïve and CRPC (higher in } \\
\text { CRPC xenografts and bone metastases over } \\
\text { hormone-naïve) }\end{array}$ \\
\hline & AR-V13 & $1 / 2 / 3 / 4 / 5 / 6 / 9$ & $6 / 9$ & Inactive & Primary tumor and mCRPC (higher in $\mathrm{mCRPC}$ ) \\
\hline & AR-V14 & $1 / 2 / 3 / 4 / 5 / 6 / 7 / 9$ & $7 / 9$ & Inactive & CRPC \\
\hline & ARv5es & Unknown & $4 / 6$ & Unknown & Primary tumor and $\mathrm{mCRPC}$ (higher in $\mathrm{mCRPC}$ ) \\
\hline & ARv56es & Unknown & $4 / 7$ & Unknown & mCRPC \\
\hline & ARv7es & Unknown & $6 / 8$ & Unknown & Primary tumor and mCRPC (higher in mCRPC) \\
\hline & ARv4es & Unknown & $3 / 5$ & Unknown & Primary tumor and $m C R P C$ (higher in $\mathrm{mCRPC}$ ) \\
\hline & ARv6es & Unknown & $5 / 7$ & Unknown & Primary tumor and mCRPC \\
\hline & Exon 1-CE4 & Unknown & 1/CE4 & Unknown & mCRPC \\
\hline & ARv2es & Unknown & $1 / 3$ & Unknown & Peritumoral, primary tumor and mCRPC \\
\hline & ARv3es & Unknown & $2 / 4$ & Unknown & Peritumoral, primary tumor and $\mathrm{mCRPC}$ \\
\hline & ARv34es & Unknown & $2 / 5$ & Unknown & Primary tumor and $\mathrm{mCRPC}$ \\
\hline $\begin{array}{l}\text { Promoter } \\
\text { usage }\end{array}$ & AR-45 & $1 \mathrm{~b} / 2 / 3 / 4 / 5 / 6 / 7 / 8$ & $1 \mathrm{~b} / 2$ & $\begin{array}{l}\text { Depends on cell } \\
\text { context }\end{array}$ & $\begin{array}{l}\text { Peritumoral, benign, primary tumor and } \\
\text { mCRPC }\end{array}$ \\
\hline
\end{tabular}

AR-V, androgen receptor variant; CE, cryptic exon; CRPC, castration-resistant prostate cancer; I, intron; mCRPC, metastatic CRPC.

Expression of AR-Vs in clinical samples has provided evidence for clinically relevant functions. For example, AR-V7 is elevated in castrate-resistant vs hormoneresponsive tumor tissues (Guo et al. 2009, Hu et al. 2009), in CRPC vs benign or localized PCa (McGrath et al. 2013) and in CRPC bone metastases compared to benign tissues, primary tumors or hormone-naïve bone metastases (Hornberg et al. 2011). Although therapydriven increases in AR-V7 expression could be due to ADT-mediated alterations to AR splicing factors, RNAbinding proteins or miRNAs (Liu et al. 2014b, Shi et al. 2015, Stockley et al. 2015), it must be noted that ligand depletion can result in increased expression of the $A R$ gene due to transcriptional autoregulation (described above) (Cai et al. 2011). As total AR gene expression is highly correlated with alternative splicing (Liu et al. 2014b, Hickey et al. 2015), the association between $A R-V$ mRNA and therapy does not necessarily equate to a biologically relevant function in terms of disease progression.

Although the associations between AR-Vs (mRNA and protein) with clinical parameters and drug resistance are compelling, the relevance of these findings has been called into question by the observation that $A R-V$ expression at the mRNA level may only be approximately $0.03-7 \%$ of the full-length transcript in CRPC metastases (Hornberg et al. 2011, Robinson et al. 2015). However, we believe that this is a poor reason to discount the biological relevance of AR-Vs. First, as full-length AR (AR-FL) expression is increased by approximately an order of magnitude in CRPC compared to hormone-sensitive disease (Hu et al. 2009), the aformentioned ratio is misleading in terms of absolute expression. Second, one study reported that AR-Vs and AR-FL proteins could exist at comparable levels in CRPC bone metastases even though much lower levels of AR-V mRNA were detected, suggesting that AR-Vs could 
be more stable than AR-FL (Hornberg et al. 2011). More broadly, direct comparison between the ligand-dependent AR-FL and ligand-independent truncated AR-Vs are problematic as the latter may require much lower protein copies to achieve robust activity. Finally, a recent study provided evidence for the concept that the low levels of AR-V expression evident after ADT allowed tumor cells to retain basal AR activity and thereby survive until more potent AR-activating mechanisms emerged ( $\mathrm{Yu}$ et al. 2014b).

Controversy surrounding the biological relevance of AR-Vs, at least in part arising from their low expression in clinical samples, has been compounded by the lack of AR-V-specific antibodies, which means that the existence of endogenous protein products for most $A R-V$ transcripts has not been verified in any biological system. AR-V7 is the exception: using an antibody specific to this variant, two groups have demonstrated that it is associated with therapy resistance and poor outcome (Efstathiou et al. 2015, Welti et al. 2016). Indeed, the recent analytical and clinical validation of an AR-V7 IHC method (Welti et al. 2016) demonstrated that it is associated with overall survival in men with CRPC, whereas AR N-terminal domain staining is not. The recent development of a specific and sensitive antibody for ARv567es (Prof. Stephen Plymate, personal communication) is also a significant step forward in the field.

Although the role of AR-Vs as a key driver of CRPC remains equivocal, recent findings have suggested that AR-V7 could have value as a predictive biomarker in CRPC. In a seminal study, Antonarakis and coworkers showed that men with detectable expression of $A R-V 7$ mRNA in CTCs had reduced response rates to enzalutamide and abiraterone (Antonarakis et al. 2014). More recent work has revealed that $A R-V 7$ transcript is also detectable in whole blood (Liu et al. 2016) and predicts poor response to abiraterone (Todenhofer et al. 2016). The predictive value of $\mathrm{AR}-\mathrm{V} 7$ is not limited to transcript expression as a recently developed CTC-based immunofluorescence assay demonstrated that nuclear expression of AR-V7 predicts worse survival after treatment with AR-targeted therapies (Scher et al. 2016). Importantly, as the efficacy of chemotherapy appears to be independent of AR-V7 expression in CTCs and tissues, AR-V7 can potentially be used to guide patient therapy (Antonarakis et al. 2015, Onstenk et al. 2015, Scher et al. 2016), an idea that is now being tested in multiple clinical trials (e.g., NCT02429193, NCT02269982, NCT02853097 and NCT02491411). Although the outcomes of these trials are eagerly awaited, it must be noted that exceptions have already been reported: a recent study found that AR-V7 status in CTCs cannot entirely predict non-response to abiraterone or enzalutamide (Bernemann et al. 2016). Given that effective alternative treatment options are still somewhat limited, this latter study raises a note of caution for clinicians.

A key question in the field has been whether AR-Vs regulate a classical AR-driven transcriptional program or whether they have distinct gene targets, with evidence for both concepts being reported (Guo et al. 2009, Hu et al. 2009, 2012, Sun et al. 2010, Chan et al. 2012, 2015, Tsai et al. 2012, Cao et al. 2014, Lu et al. 2015). Recently, work from Dehm's group has provided a possible explanation for these discrepant findings by identifying proliferative vs anti-proliferative AR gene signatures mediated by differences in DHT dose or AR expression, with the former mitotic gene signature resembling that driven by AR-Vs (Li et al. 2013). Multiple other lines of evidence support the idea that AR-Vs are likely to largely recapitulate AR-FL function. First, a recent study from our group found that AR-FL and ARv567es cistromes were highly concordant, with both exhibiting a preference for canonical inverted repeat androgen response elements (Chan et al. 2015). Second, dimerization of AR-Vs is required for their transcriptional activity and utilizes the same interaction surface as AR-FL (Chan et al. 2015, Xu et al. 2015). Finally, transcriptional repression of AR-Vs by binding of the transcription factor FOXO1 to transcription activation unit 5 (TAU5) in the NTD revealed that, like AR-FL, they require this domain for transcriptional activity.

Although we favor the idea that AR-Vs generally regulate a classical androgen transcriptome for the reasons described previously, we note that most studies to date have assessed AR-V activity in isolation. The finding that AR-Vs can heterodimerize with AR-FL or with other AR-Vs (Sun et al. 2010, Cao et al. 2014, Xu et al. 2015) raises the possibility that the nature and relative expression of different AR-Vs and AR-FL in single cells could influence distinct transcriptional outputs.

\section{AR coregulator alterations in CRPC}

In the non-pathological state, the interplay of AR with its coregulators within the nucleus is tightly controlled and is essential for the regulation of genomic, ligand-activated functions (Mestayer et al. 2003, Xu et al. 2009a). In the malignant and castration-resistant states, deregulation of this interplay is common and frequently manifested by increased expression and activity of AR coactivators with a concomitant inhibition or loss of AR corepressors

Published by Bioscientifica Ltd 
(Supplementary Table 3). One class of coregulators that plays a key role in facilitating aberrant AR signaling in CRPC is the steroid receptor coactivators (SRC-1, SRC-2 and SRC-3). The expression of all 3 SRCs is frequently elevated in primary disease and associated with disease progression and poor outcome (Fujimoto et al. 2001, Gregory et al. 2001, Linja et al. 2004, Agoulnik et al. 2006, Taylor et al. 2010). Moreover, aberrant upregulation of the SRCs is even more pronounced in CRPC (Taylor et al. 2010, Grasso et al. 2012, Cancer Genome Atlas Research 2015, Robinson et al. 2015, Beltran et al. 2016, Kumar et al. 2016). Mechanistically, increased SRC expression enhances AR signaling in low androgen settings and also potentiates alternative ligand usage (Agoulnik \& Weigel 2009, Foley \& Mitsiades 2016). The clinical relevance of these factors is perhaps best emphasized by the finding that constitutive overexpression of SRC-2 in the mouse prostate epithelium was sufficient for the development of prostate adenocarcinoma in mice, whereas $S R C-2$ depletion prevented CRPC development in PTEN-deficient mice (Qin et al. 2014).

Another type of AR regulatory molecule is the 'pioneer' factor, with the archetypal example being Forkhead Box A1 (FOXA1). FOXA1 is not a classic transcriptional coactivator but rather serves to open sites of condensed chromatin to facilitate - or 'pioneer' - AR binding, resulting in enhanced transcriptional activity (Wang et al. 2009). Amplification and overexpression of FOXA1 have been detected in primary tumors but is more common in metastatic CRPC, highlighting its role in persistent AR signaling in the castrate state (Jain et al. 2011, Grasso et al . 2012, Cancer Genome Atlas Research 2015, Robinson et al. 2015, Kumar et al. 2016). Overexpression of FOXA1 has been associated with poor outcome and AR expression (Jain et al. 2011, Sahu et al. 2011, Gerhardt et al. 2012, Robinson et al. 2014). Mechanistically, high levels of FOXA1 in tumor cells may enhance AR:chromatin interactions when androgen levels are low and also enable binding of AR to non-canonical sites, both of which can drive a CRPC gene expression program (Wang et al. 2009, Robinson et al. 2014). Interestingly, the converse also appears to be true: a number of studies have found that loss of FOXA1 can enable androgen-independent AR chromatin binding at non-canonical sites throughout the genome, and this cistromic reprogramming has been associated with enhanced AR signaling in CRPC (Sahu et al. 2011, Wang et al. 2011, Jin et al. 2014). Thus, maintaining stable FOXA1 expression and activity appears to be an important requirement for the healthy prostate, with deregulation in either direction being potentially oncogenic (see Yang \& Yu 2015 for a recent review on this topic). This phenomenon is supported by clinical observations: although FOXA1 amplification is relatively common in CRPC, loss-of-function FOXA1 mutations have also been found at a high incidence (Barbieri et al. 2012, Grasso et al. 2012, Gao et al. 2014, Robinson et al. 2015, Kumar et al. 2016).

GATA2 is another AR pioneer factor with a multifaceted role in the AR signaling axis: it promotes AR (and AR-V) expression, is required for AR transcriptional activity and enhances AR:chromatin associations (Bohm et al. 2009, Seo et al. 2013, He et al. 2014). Given this triumvirate of oncogenic functions, it is not surprising that GATA2 is overexpressed in CRPC and associated with poor outcome (Chiang et al. 2014, He et al. 2014). GATA2 also has an intimate, bidirectional relationship with FOXA1, with important implications for development and progression of CRPC (Zhao et al. 2016). Although targeting FOXA1 is complicated by its putative dual role in PCa, strategies to suppress GATA2 may have higher feasibility as evidence to date indicates that it plays a positive role in driving CRPC growth.

Alterations to AR corepressors also play a key role in CRPC. For example, loss of activity of the key nuclear receptor corepressors NCOR1 and NCOR2, by either mutation and/or deletion, is relatively common in primary PCa and enriched in CRPC (Grasso et al. 2012, Cancer Genome Atlas Research 2015, Robinson et al. 2015, Kumar et al. 2016). NCORs compete with key AR coactivators, such as p300 and SCR-1, for binding to the ligand-activated receptor, thereby inhibiting its transcriptional activity (Yoon \& Wong 2006). Thus, loss of these factors facilitates AR signaling in malignant tissues. Another negative regulator of AR activity, SPOP, was the most commonly mutated factor in an early study of localized PCa (Barbieri et al. 2012), and more recent genomics programs of both primary disease and CRPC have validated this finding (Grasso et al. 2012, Cancer Genome Atlas Research 2015, Robinson et al. 2015, Kumar et al. 2016). SPOP is an E3 ligase that promotes the ubiquitination and degradation of AR and SRC-3, reducing the latter's capacity to enhance AR transcriptional activity (Geng et al. 2013, 2014). All SPOP mutants identified to date lack the capacity to interact with SRC-3 (Geng et al. 2013) or AR itself (An et al. 2014, Geng et al. 2014), resulting in the stabilization of these substrates. Importantly, the SPOP-binding motif resides in AR's hinge domain; therefore, AR-Vs lacking this region (i.e. AR-V2, AR-V5, AR-V7 and AR-V4, but not ARv567es) can escape SPOP-mediated destruction (An et al. 2014).

Published by Bioscientifica Ltc. 


\section{New drugs and emerging strategies to target persistent AR signaling driving CRPC}

Persistent AR signaling as a driver of CRPC has inspired the hunt for new AR-directed drugs; a subset of agents in clinical development are illustrated in Fig. 2, whereas Supplementary Table 4 comprises a more comprehensive list.

\section{Novel androgen receptor antagonists}

Given the recent success of enzalutamide, the search for and development of novel AR-LBD antagonists remains a key priority. One such antagonist is ARN-509, a new-generation anti-androgen with similar structure and mechanism of action to enzalutamide but with potentially increased potency, better pharmacological characteristics and improved patient tolerability (Clegg et al. 2012). Although the development of ARN-509 is ongoing, it must be noted that an AR mutation, F877L, that can confer resistance to this agent has already been reported (Joseph et al. 2013, Korpal et al. 2013). Another promising $\mathrm{AR}$ antagonist in clinical development is ODM-201, which is reported to be more potent that enzalutamide in inhibiting AR nuclear translocation (Moilanen et al. 2015). Moreover, ODM-201 potentially has the added benefit of activity against AR mutants commonly found in CRPC, namely, T878A, W742L and F877L mutant (Fizazi et al. 2014, Moilanen et al. 2015).
Phase III clinical trials to evaluate the safety and efficacy of ODM-1 in non-metastatic CRPC patients (NCT02200614) and the efficacy of ODM-1 in combination with ADT and docetaxel in patients with metastatic hormone-naïve $\mathrm{PCa}$ (NCT02799602) are ongoing.

\section{Targeting androgen receptor expression}

Although AR antagonists remain a key focus of research and industry, the realization that ligand-independent forms of the AR, such as mutants and variants, arise in CRPC has elicited novel strategies aimed at suppressing all forms of the AR. In this respect, agents that degrade or inhibit the expression of AR represent a rational approach. One interesting candidate is galeterone, which in addition to promoting the degradation of AR and AR-Vs (Yu et al. 2014a, Kwegyir-Afful et al. 2015) also has activity as an LBD antagonist and an inhibitor of cytochrome P450 17alpha-hydroxylase/17,20-lyase (CYP17), an enzyme essential for the biosynthesis of androgens (Njar \& Brodie 2015, Bastos \& Antonarakis 2016). Although this proposed 'triple method of action' is exciting, it must be noted that the degrader activity of galeterone is somewhat controversial; it may simply be a by-product of abrogating ligand binding (Yu et al. 2014a). Notwithstanding these concerns, the putative anti-AR-V activity of galeterone led to the development of a phase III clinical trial (ARMOR3-SV; NCT02438007) in which men with AR-V7-positive disease, as assessed

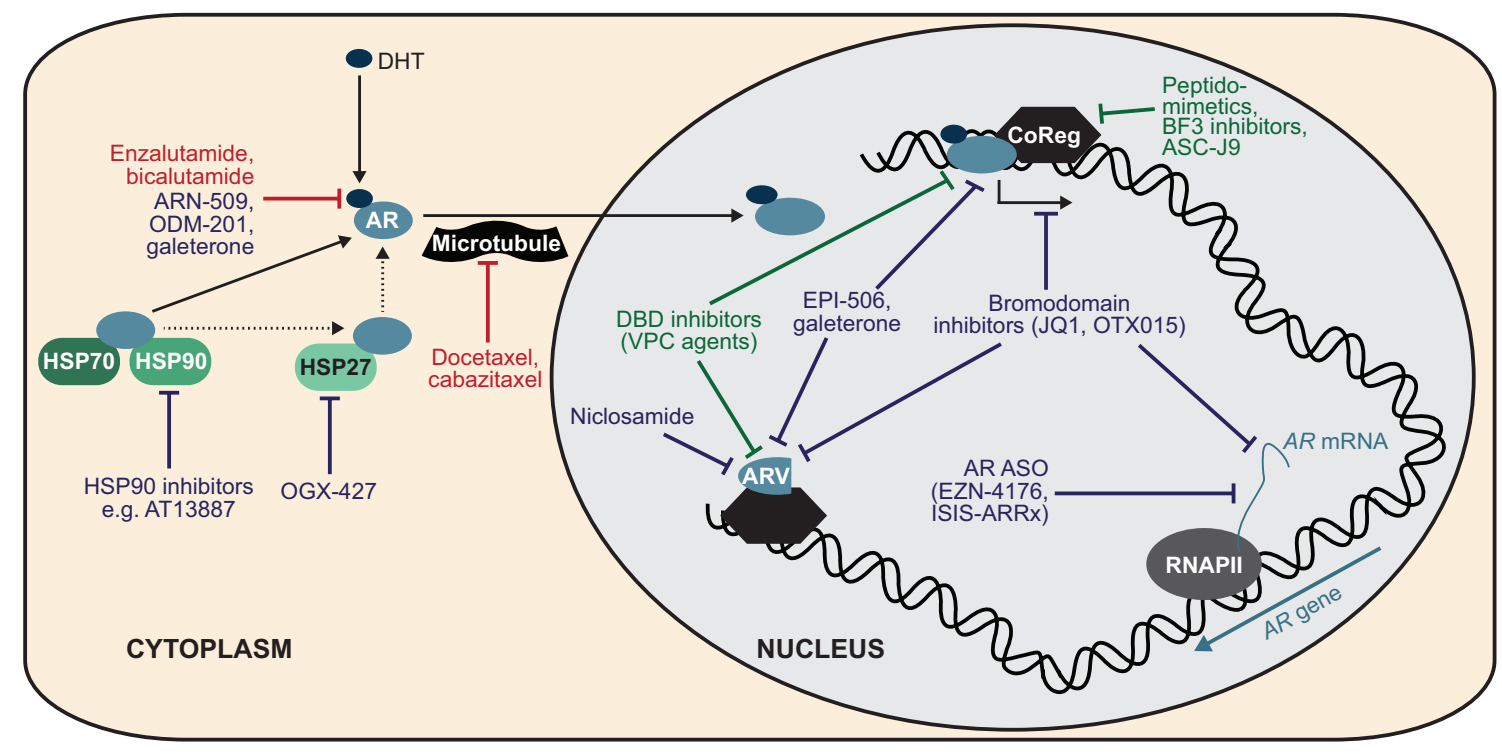

Figure 2

Novel strategies to target persistent androgen receptor signaling in CRPC. Recently approved agents are shown in red; agents in clinical trials are shown in blue; novel agents still in pre-clinical development are shown in green. CoReg, coregulator; HSP, heat shock protein. 
by the AdnaGen assay (Antonarakis et al. 2014), were randomized to galeterone or enzalutamide treatment arms. Unfortunately, this trial was discontinued in July 2016 due to lack of an improvement in radiographic progression-free survival for galeterone vs enzalutamide; the fate of this drug is now unclear.

Ligand-bound AR undergoes cycles of ubiquitination and deubiquitination when engaging in its chromatinassociated transcriptional activities, and turnover of polyubiquitinated AR by the ubiquitin-proteasome system (UPS) is important for the stimulation and regulation of AR-driven transcription (Voutsadakis \& Papandreou 2012). In addition to SPOP, several other E3 ligases including Siah2 (Qi et al. 2013), RNF6 (Xu et al. 2009b), MDM2 (Lin et al. 2002) and CHIP (Sarkar et al. 2014) have been shown to mediate AR ubiquitylation, and these factors collectively enable another level of complexity in terms of AR regulation. Elucidating mechanisms underlying AR degradation has facilitated the rational design of proteolysis-targeting chimeras (PROTACs), which link an AR-binding element to a degron tag, such as an E3 ligaserecruiting moiety (Tang et al. 2009) or a hydrophobic tag (Gustafson et al. 2015), resulting in targeting of the AR to the UPS for degradation. Several AR-targeting PROTACs are being intensively pre-clinically characterized but are yet to reach clinical trials.

Niclosamide was identified in a screen for drugs that inhibit AR-V7 transcriptional activity and specifically causes AR-V7, but not AR-FL, degradation via a proteasome-dependent mechanism (Liu et al. 2014a, 2015). Importantly, this drug potentiates the effects of enzalutamide in vitro and in vivo and resensitizes enzalutamide-resistant prostate cancer cells (Liu et al. 2014a, 2015), findings that have elicited a phase I trial to assess the utility of niclosamide in combination with enzalutamide for treating AR-V7-positive CRPC (NCT02532114).

Inhibition of $A R$ gene transcription, as opposed to degradation of AR protein, is another promising therapeutic strategy for the suppression of all forms of the AR that are active CRPC. The recent finding that retinoic acid-related orphan receptor $\gamma(\mathrm{ROR}-\gamma)$ is a key regulator of $A R$ gene transcription led to the pre-clinical assessment of ROR- $\gamma$ antagonists (Wang et al. 2016). These agents effectively reduced the expression and activity of AR-FL and AR-V7, thereby inhibiting tumor growth and metastasis, highlighting the potential of targeting upstream regulators of $A R$ gene transcription (Wang et al. 2016). Another means to more specifically target $A R$ gene expression is the use of antisense oligonucleotides (ASOs). EZN-4176, an ASO that targets exon 4, demonstrated an impressive activity in pre-clinical studies (Zhang et al. 2011). Unfortunately, EZN-4176 failed phase I trials in CRPC due to poor $A R$ knockdown in the clinical setting and minimal antitumor activity (Bianchini et al. 2013). More recently, an exon 1-targeting ASO with improved tissue half-life and activity against enzalutamide-resistant models and CRPC patient-derived xenografts was developed (Yamamoto et al. 2015). One advantage of this latter ASO is that targeting exon 1 will theoretically yield activity against all C-terminally truncated forms of the AR and LBD mutants.

\section{Targeting DNA binding and N-terminal functions of AR}

Structural knowledge of the AR-LBD, the known 'druggability' of ligand-binding pockets and the relative ease of screening for LBD-inhibiting agents are all reasons for the past focus AR antagonists. By contrast, the development of strategies to block other key functional domains of the AR such as the DBD and NTD is more complicated. Nevertheless, recent progress has yielded promising candidates. For example, two agents designed to block the binding of AR to chromatin, VPC-14228 and VPC-14449, are in early clinical development, with both exhibiting potent anti-transcriptional activity against AR-FL and ARv567es as well as anti-growth activity in enzalutamide-resistant models (Dalal et al. 2014, Li et al. 2014). Despite the intrinsically disordered nature of the AR-NTD, which has greatly hindered its structural characterization, agents targeting this domain have also been developed. EPI-001 interacts with and covalently binds to the TAU5 domain in the AF-1 region of the AR-NTD (De Mol et al. 2016), thereby inhibiting AR:coactivator interactions (e.g. CBP and RAP74) and attenuating AR and AR-V transcriptional activity (Andersen et al. 2010, Myung et al. 2013). Importantly, EPI-001 enhanced the therapeutic response to docetaxel in CRPC cells harboring both AR-FL and AR-V7, a finding that has implications for combinatorial therapy (Martin et al. 2015). Although EPI-001 was reported to selectively inhibit AR over other nuclear receptor family members (Andersen et al. 2010), a recent study found that it inhibits the growth of AR-negative cells, at least partly due to off-target effects against proliferator-activated receptor- $\gamma$ activity (Brand et al. 2015). EPI-001 is a mixture of EPI-002, EPI-003, EPI004 and EPI-005 stereoisomers, and more recent work has focused on elucidating the activities of each with a view 
toward improving target specificity. For example, EPI002 is reported to have improved anti-tumoral activity compared to EPI-001, with activity in the context of AR coactivator (SRC1-3 or p300) overexpression, gainof-function AR mutations (both AR-NTD and AR-LBD mutants) and AR-V expression (Yang et al. 2016). The oral prodrug form of EPI-002, referred to as EPI-506, displayed strong binding to AR and low toxicity in mice (Myung et al. 2013). EPI-506 is currently under phase I/II clinical testing in post-abiraterone and post-enzalutamide settings, with initial results expected in 2017 (NCT02606123).

\section{Targeting androgen receptor coregulators}

Given the known dependence of persistent AR signaling on key coregulators, the concept of directly targeting these factors has long been mooted. Recent reviews have described in detail the current state-of-play in terms of targeting key members of the AR interactome (Biron \& Bedard 2015, Foley \& Mitsiades 2016), including chaperones (HSP90, HSP27 and others), pioneer factors (e.g. FOXA1 and GATA2) and transcriptional coactivators. In this section, we will highlight some key opportunities in this field.

One coregulator-targeted strategy involves directly blocking AR:coregulator interactions. This approach has been achieved using peptides that mimic interaction surfaces. For example, two SRC-1-derived peptides (corresponding to amino acids 1050-1150 and 1050-1240 of SRC-1) effectively inhibited AR-FL and AR-V7 activity by disrupting AR:SRC-1/SRC-2 as well as AR-NTD:ARLBD interactions (Nakka et al. 2013). Although peptides have high specificity and are a cheap and effective screening tool in vitro, poor stability in vivo limits their clinical utility. Peptidomimetics combine the specificity of peptides with the desirable pharmacological attributes of small molecules, such as stability and bioavailability. The peptidomimetic D2 was designed to mimic the LXXLL motif, which is found in many nuclear receptor coregulators (Ravindranathan et al. 2013). D2 effectively disrupted the interaction between AR and the coactivator PELP1, which contains 10 LXXLL motifs, thereby blocking AR nuclear localization and transactivation and prostate cancer growth (Ravindranathan et al. 2013). Although numerous other LXXLL-derived peptidomimetic inhibitors of AR:coactivator interactions are in pre-clinical development (Biron \& Bedard 2015), it must be noted that targeting this motif may be an ineffective strategy in the case of AR-V-driven disease (Ravindranathan et al. 2013).
Thus, the elucidation of other protein:protein interaction surfaces and motifs is required to develop novel, selective inhibitors of AR:coregulator interactions.

Strategies to target coregulators that require no prior knowledge of the AR:coregulator interface are also being developed. An exciting example of such an approach is provided by the recent demonstration of potent preclinical efficacy of bromodomain and extra-terminal (BET) inhibitors. BET family members bind to acetyl residues on histones and other chromatin-associated factors and thereby act as key transcriptional regulators. Recently, an interaction between the AR-NTD and the BET factor BRD4 was identified (Asangani et al. 2014). Disruption of this interaction with a small-molecule inhibitor of BRD4, JQ1, blocked AR chromatin association, transcriptional activity and AR-mediated PCa growth (Asangani et al. 2014). More recently, a pan-BET degrader (based on PROTAC technology) was shown to have potent anti-CRPC activity (Raina et al. 2016). Importantly, we and others have shown that BET inhibition has a dual mechanism of action, suppressing not only AR transcriptional activity but also $A R$ gene transcription (Chan et al. 2015, Raina et al. 2016). This finding, combined with the mapping of the BRD4 interaction surface to the AR-NTD, suggests that BET inhibitors would have activity in CRPC driven by AR-LBD mutants and/or AR-Vs, a prediction that has been experimentally substantiated (Chan et al. 2015, Asangani et al. 2016, Raina et al. 2016).

Targeting pioneer factors to suppress hormone receptor activity is an emerging concept (Nakshatri \& Badve 2007). It must be noted that there is concern about the potential utility of inhibiting FOXA1, given that it can seemingly act to both promote and suppress AR-mediated CRPC growth depending on context (see above). By contrast, a number of factors have converged to make the pioneer factor GATA2 an attractive target (He et al. 2014): (i) GATA2 enhances both the expression and activity of AR; (ii) GATA2 is also required for signaling by AR-Vs; (iii) a small-molecule inhibitor of GATA2 (K7174) is available and (iv) GATA2 is reported to have an AR-independent role in driving chemoresistance in prostate cancer (Vidal et al. 2015), meaning that its targeting could potentially suppress multiple oncogenic pathways. However, GATA2 plays a key role in multiple aspects of normal physiology, most notably hematopoiesis and angiogenesis, and GATA2 deficiency can result in susceptibility to infections, leukemia and other blood disorders (Hsu et al. 2015); any future efforts to develop GATA2 inhibitors for CRPC will need to take this into account. 


\section{Why are prostate cancer cells addicted to androgen receptor signaling?}

In the face of a concerted attack in the way of sequential first- and second-line AR-targeted therapies, prostate cancer cells adapt in such a way that AR (in most cases) remains the dominant driver of disease. This exquisite dependence on an individual driver of malignancy is an example of the phenomenon known as oncogene addiction (Weinstein 2002, Pagliarini et al. 2015). Although many mechanisms explaining the means by which AR signaling is maintained and/or adapts to circumvent all current forms of AR-targeted therapies in PCa have been elucidated, some of which were described previously, a key question that is rarely explored is simply: what underlies the addiction of PCa to AR?

Answering this question is not straightforward, but an understanding of the role of AR in normal physiology provides clues. Indeed, although this review has focused on the role of AR in prostate cancer, it is important to remember that the androgen/AR signaling axis regulates the development and maintenance of primary and secondary male sexual characteristics, plays a key role in female fertility and also has a plethora of functions in various non-reproductive tissues of both genders (De Gendt \& Verhoeven 2012). Given that loss of AR would have dire repercussions for organismal viability, it is logical to expect that cells have developed fail-safe mechanisms to ensure the maintenance of functional AR signaling. It is also worth noting that such mechanisms are likely to be more active in men who have a single $\mathrm{X}$ chromosome and hence a single copy of the $A R$ gene. In response to AR-targeted therapies, prostate cancer cells could readily 'hijack' this intrinsic capacity to sustain AR activity. One pertinent example of this concept is the capacity of AR to auto-regulate its own expression, which constitutes an important homeostatic mechanism in normal cells but is exploited in CRPC to upregulate AR expression (Cai et al. 2011). Further investigation of normal prostate physiology will likely provide key insights into the intrinsic mechanisms underlying persistent AR signaling.

The concept of a 'one-step' remedy for cancers addicted to a specific oncogene (Weinstein 2002) has clearly not been attainable in the case of AR. However, the path to curative therapy can be guided by lessons learnt from both CRPC and other cancers that exhibit unequivocal dependence on a particular oncogene. These lessons have taught us that outcomes can be improved by simply making better inhibitors (e.g. enzalutamide) but that more sophisticated strategies such as 'vertical' and/or 'parallel' combination therapies (Pagliarini et al. 2015) will likely be required to achieve substantial gains. Another observation of relevance to this discussion was obtained by Zhang and coworkers who noted that combining two distinct modes of pharmacological inhibition of a single driver oncogene, Bcr-Abl, in chronic myeloid leukemia reduced the occurrence of resistance mechanisms associated with either mode alone (Zhang et al. 2010). We favor the idea that combining current ligand-centric strategies with agents that block other aspects of AR function, such as DNA binding or N-terminal transcriptional activity, will be an effective strategy in the future to curtail therapy resistance and thereby reduce the rates of CRPC.

Although this review has focused on persistence of AR signaling in CRPC, we note that trans-differentiation of tumors to an AR-independent, neuroendocrine-like state is an emerging clinical issue, albeit relatively uncommon (Tilki \& Evans 2014, Beltran et al. 2016). However, as the potency and selectivity of AR inhibitors increase, this disease state may occur more frequently (Beltran 2016). Interestingly, this phenomenon may be generalizable as similar phenotypic transformations have been observed in other tumor types in response to targeted therapies (Sequist et al. 2011). Within this context, therapeutic strategies aimed at modulating the activity of AR, as opposed to a dogmatic focus on inhibition, may have benefit: one example is bipolar androgen therapy (Schweizer et al. 2015), which could potentially block tumor cell trans-differentiation by sequential stimulation of both AR activation (supraphysiologic testosterone) and inhibition (ADT).

\section{Concluding remarks and future directions}

Notwithstanding the recent identification and characterization of AR-independent forms of CRPC (Tilki \& Evans 2014, Beltran et al. 2016), the majority of CRPC tumors remain driven by persistent AR signaling. Mechanisms underlying this persistence, and potential strategies to target it, were outlined previously. To finish, we list some key outstanding questions and comments that we believe represent key avenues of future research:

- AR signaling-driven castration resistance can be acquired via multiple and convergent events in different metastases, a phenomenon explained by the selective pressure of ADT (Gundem et al. 2015). What are the therapeutic consequences of the co-existence of multiple forms of persistent, aberrant AR signaling in
(C) 2016 Society for Endocrinology Printed in Great Britain
Published by Bioscientifica Ltd 
the same patient? How do we best identify and target the drug-resistant, lethal clones?

- Many different structurally aberrant androgen receptors, such as specific point mutants and truncated variants, have been identified. How do we (comprehensively and rapidly) elucidate the molecular functions of each? Moreover, given the potential for heterodimerization of distinct forms of the AR, how do we optimally model the consequences of interplay between them?

- AR coregulators are essential for the activity of AR in normal cells (Mestayer et al. 2003, Xu et al. 2009a). Can we push AR towards its 'normal' function by shaping, both qualitatively and quantitatively, the AR interactome?

- There is a growing realization that no single AR-targeting drug per se will eliminate CRPC due to the constant adaptive evolution of the disease in the face of therapy. Combinatorial therapies have high potential to overcome this issue. However, we urgently require better predictive tools/biomarkers to guide the application of such therapies and identify the patients most likely to receive benefit.

\section{Supplementary data}

This is linked to the online version of the paper at http://dx.doi.org/10.1530/ ERC-16-0422.

\section{Declaration of interest}

The authors declare that there is no conflict of interest that could be perceived as prejudicing the impartiality of this review.

\section{Funding}

This work was supported by funding from the National Health and Medical Research Council of Australia (ID 1008349 to W D T; ID 1083961 to L A S and W D T) and a Prostate Cancer Research Programs Transformative Impact Award from the US Department of Defense (W81XWH-13-2-0093 to W D T and L A S).

\section{Acknowledgements}

The authors thank Dr Esmaeil Ebrahimie for useful discussions. They acknowledge that many important studies relevant to this review are not cited herein, and apologize for omissions due to limitations of both space and scope.

\section{References}

Agoulnik IU \& Weigel NL 2009 Coactivator selective regulation of androgen receptor activity. Steroids 74 669-674. (doi:10.1016/j. steroids.2009.02.007)
Agoulnik IU, Vaid A, Nakka M, Alvarado M, Bingman WE 3rd, Erdem H, Frolov A, Smith CL, Ayala GE, Ittmann MM, et al. 2006 Androgens modulate expression of transcription intermediary factor 2 , an androgen receptor coactivator whose expression level correlates with early biochemical recurrence in prostate cancer. Cancer Research $6 \mathbf{6}$ 10594-10602. (doi:10.1158/0008-5472.CAN-06-1023)

Ahmadi H \& Daneshmand S 2013 Androgen deprivation therapy: evidence-based management of side effects. BJU International 111 543-548. (doi:10.1111/j.1464-410X.2012.11774.x)

Alsop K, Thorne H, Sandhu S, Hamilton A, Mintoff C, Christie E, Spruyt O, Williams S, McNally O, Mileshkin L, et al. 2016 A community-based model of rapid autopsy in end-stage cancer patients. Nature Biotechnology 34 1010-1014. (doi:10.1038/ nbt.3674)

An J, Wang C, Deng Y, Yu L \& Huang H 2014 Destruction of full-length androgen receptor by wild-type SPOP, but not prostate-cancerassociated mutants. Cell Reports 6 657-669. (doi:10.1016/j. celrep.2014.01.013)

Andersen RJ, Mawji NR, Wang J, Wang G, Haile S, Myung JK, Watt K, Tam T, Yang YC, Banuelos CA, et al. 2010 Regression of castraterecurrent prostate cancer by a small-molecule inhibitor of the amino-terminus domain of the androgen receptor. Cancer Cell $\mathbf{1 7}$ 535-546. (doi:10.1016/j.ccr.2010.04.027)

Antonarakis ES, Lu C, Wang H, Luber B, Nakazawa M, Roeser JC, Chen Y, Mohammad TA, Chen Y, Fedor HL, et al. 2014 AR-V7 and resistance to enzalutamide and abiraterone in prostate cancer. New England Journal of Medicine 371 1028-1038. (doi:10.1056/ NEJMoa1315815)

Antonarakis ES, Lu C, Luber B, Wang H, Chen Y, Nakazawa M, Nadal R, Paller CJ, Denmeade SR, Carducci MA, et al. 2015 Androgen receptor splice variant 7 and efficacy of taxane chemotherapy in patients with metastatic castration-resistant prostate cancer. JAMA Oncology 1 582-591. (doi:10.1001/jamaoncol.2015.1341)

Asangani IA, Dommeti VL, Wang X, Malik R, Cieslik M, Yang R, EscaraWilke J, Wilder-Romans K, Dhanireddy S, Engelke C, et al. 2014 Therapeutic targeting of BET bromodomain proteins in castrationresistant prostate cancer. Nature 510 278-282. (doi:10.1038/ nature13229)

Asangani IA, Wilder-Romans K, Dommeti VL, Krishnamurthy PM, Apel IJ, Escara-Wilke J, Plymate SR, Navone NM, Wang S, Feng FY, et al. 2016 BET bromodomain inhibitors enhance efficacy and disrupt resistance to AR antagonists in the treatment of prostate cancer. Molecular Cancer Research 14 324-331. (doi:10.1158/15417786.MCR-15-0472)

Azad AA, Volik SV, Wyatt AW, Haegert A, Le Bihan S, Bell RH, Anderson SA, McConeghy B, Shukin R, Bazov J, et al. 2015 Androgen receptor gene aberrations in circulating cell-free DNA: biomarkers of therapeutic resistance in castration-resistant prostate cancer. Clinical Cancer Research 21 2315-2324. (doi:10.1158/1078-0432.CCR-142666)

Balbas MD, Evans MJ, Hosfield DJ, Wongvipat J, Arora VK, Watson PA, Chen Y, Greene GL, Shen Y \& Sawyers CL 2013 Overcoming mutation-based resistance to antiandrogens with rational drug design. eLife 2 e00499. (doi:10.7554/elife.00499)

Barbieri CE, Baca SC, Lawrence MS, Demichelis F, Blattner M, Theurillat JP, White TA, Stojanov P, Van Allen E, Stransky N, et al. 2012 Exome sequencing identifies recurrent SPOP, FOXA1 and MED12 mutations in prostate cancer. Nature Genetics 44 685-689. (doi:10.1038/ng.2279)

Bastos DA \& Antonarakis ES 2016 Galeterone for the treatment of advanced prostate cancer: the evidence to date. Drug Design, Development and Therapy 10 2289-2297. (doi:10.2147/DDDT. S93941)

Beer TM, Armstrong AJ, Rathkopf DE, Loriot Y, Sternberg CN, Higano CS, Iversen P, Bhattacharya S, Carles J, Chowdhury S, et al. 2014 Enzalutamide in metastatic prostate cancer before 
chemotherapy. New England Journal of Medicine 371 424-433. (doi:10.1056/NEJMoa1405095)

Beltran H 2016 Update on the biology and management of neuroendocrine prostate cancer. Clinical Advances in Hematology and Oncology 14 513-515.

Beltran H, Yelensky R, Frampton GM, Park K, Downing SR, MacDonald TY, Jarosz M, Lipson D, Tagawa ST, Nanus DM, et al. 2013 Targeted next-generation sequencing of advanced prostate cancer identifies potential therapeutic targets and disease heterogeneity. European Urology 63 920-926. (doi:10.1016/j. eururo.2012.08.053)

Beltran H, Prandi D, Mosquera JM, Benelli M, Puca L, Cyrta J, Marotz C, Giannopoulou E, Chakravarthi BV, Varambally S, et al. 2016 Divergent clonal evolution of castration-resistant neuroendocrine prostate cancer. Nature Medicine 22 298-305. (doi:10.1038/nm.4045)

Bernemann C, Schnoeller TJ, Luedeke M, Steinestel K, Boegemann M, Schrader AJ \& Steinestel J 2016 Expression of AR-V7 in circulating tumour cells does not preclude response to next generation androgen deprivation therapy in patients with castration resistant prostate cancer. European Urology [in press]. (doi:10.1016/j. eururo.2016.07.021)

Berrevoets CA, Veldscholte J \& Mulder E 1993 Effects of antiandrogens on transformation and transcription activation of wild-type and mutated (LNCaP) androgen receptors. Journal of Steroid Biochemistry and Molecular Biology 46 731-736. (doi:10.1016/09600760(93)90313-L)

Berrevoets CA, Umar A, Trapman J \& Brinkmann AO 2004 Differential modulation of androgen receptor transcriptional activity by the nuclear receptor co-repressor (N-CoR). Biochemical Journal 379 731-738. (doi:10.1042/bj20031456)

Bianchini D, Omlin A, Pezaro C, Lorente D, Ferraldeschi R, Mukherji D, Crespo M, Figueiredo I, Miranda S, Riisnaes R, et al. 2013 First-inhuman Phase I study of EZN-4176, a locked nucleic acid antisense oligonucleotide to exon 4 of the androgen receptor mRNA in patients with castration-resistant prostate cancer. British Journal of Cancer 109 2579-2586. (doi:10.1038/bjc.2013.619)

Biron E \& Bedard F 2015 Recent progress in the development of protein-protein interaction inhibitors targeting androgen receptorcoactivator binding in prostate cancer. Journal of Steroid Biochemistry and Molecular Biology 161 36-44. (doi:10.1016/j. jsbmb.2015.07.006)

Bohm M, Locke WJ, Sutherland RL, Kench JG \& Henshall SM 2009 A role for GATA-2 in transition to an aggressive phenotype in prostate cancer through modulation of key androgen-regulated genes. Oncogene 28 3847-3856. (doi:10.1038/onc.2009.243)

Brand LJ, Olson ME, Ravindranathan P, Guo H, Kempema AM, Andrews TE, Chen X, Raj GV, Harki DA \& Dehm SM 2015 EPI-001 is a selective peroxisome proliferator-activated receptor-gamma modulator with inhibitory effects on androgen receptor expression and activity in prostate cancer. Oncotarget $63811-3824$ (doi:10.18632/oncotarget.2924)

Brooke GN, Parker MG \& Bevan CL 2008 Mechanisms of androgen receptor activation in advanced prostate cancer: differential co-activator recruitment and gene expression. Oncogene $\mathbf{2 7}$ 2941-2950. (doi:10.1038/sj.onc.1210955)

Buchanan G, Yang M, Cheong A, Harris JM, Irvine RA, Lambert PF, Moore NL, Raynor M, Neufing PJ, Coetzee GA, et al. 2004 Structural and functional consequences of glutamine tract variation in the androgen receptor. Human Molecular Genetics 13 1677-1692. (doi:10.1093/hmg/ddh181)

Cai C, He HH, Chen S, Coleman I, Wang H, Fang Z, Chen S, Nelson PS Liu XS, Brown M, et al. 2011 Androgen receptor gene expression in prostate cancer is directly suppressed by the androgen receptor through recruitment of lysine-specific demethylase 1. Cancer Cell $\mathbf{2 0}$ 457-471. (doi:10.1016/j.ccr.2011.09.001)
Callewaert L, Van Tilborgh N \& Claessens F 2006 Interplay between two hormone-independent activation domains in the androgen receptor. Cancer Research 66 543-553. (doi:10.1158/0008-5472. CAN-05-2389)

Cancer Genome Atlas Research Network 2015 The molecular taxonomy of primary prostate cancer. Cell 163 1011-1025. (doi:10.1016/j. cell.2015.10.025)

Cao B, Qi Y, Zhang G, Xu D, Zhan Y, Alvarez X, Guo Z, Fu X, Plymate SR, Sartor O, et al. 2014 Androgen receptor splice variants activating the full-length receptor in mediating resistance to androgen-directed therapy. Oncotarget 5 1646-1656. (doi:10.18632/ oncotarget.1802)

Carreira S, Romanel A, Goodall J, Grist E, Ferraldeschi R, Miranda S, Prandi D, Lorente D, Frenel JS, Pezaro C, et al. 2014 Tumor clone dynamics in lethal prostate cancer. Science Translational Medicine 6 254ra125. (doi:10.1126/scitranslmed.3009448)

Chan SC, Li Y \& Dehm SM 2012 Androgen receptor splice variants activate androgen receptor target genes and support aberrant prostate cancer cell growth independent of canonical androgen receptor nuclear localization signal. Journal of Biological Chemistry 287 19736-19749. (doi:10.1074/jbc.M112.352930)

Chan SC, Selth LA, Li Y, Nyquist MD, Miao L, Bradner JE, Raj GV, Tilley WD \& Dehm SM 2015 Targeting chromatin binding regulation of constitutively active AR variants to overcome prostate cancer resistance to endocrine-based therapies. Nucleic Acids Research 43 5880-5897. (doi:10.1093/nar/gkv262)

Chen CD, Welsbie DS, Tran C, Baek SH, Chen R, Vessella R, Rosenfeld MG \& Sawyers CL 2004 Molecular determinants of resistance to antiandrogen therapy. Nature Medicine 10 33-39. (doi:10.1038/nm972)

Chen G, Wang X, Zhang S, Lu Y, Sun Y, Zhang J, Li Z \& Lu J 2005 Androgen receptor mutants detected in recurrent prostate cancer exhibit diverse functional characteristics. Prostate 63 395-406. (doi:10.1002/pros.20191)

Chen EJ, Sowalsky AG, Gao S, Cai C, Voznesensky O, Schaefer R, Loda M, True LD, Ye H, Troncoso P, et al. 2015 Abiraterone treatment in castration-resistant prostate cancer selects for progesterone responsive mutant androgen receptors. Clinical Cancer Research $\mathbf{2 1}$ 1273-1280. (doi:10.1158/1078-0432.CCR-14-1220)

Chiang YT, Wang K, Fazli L, Qi RZ, Gleave ME, Collins CC, Gout PW \& Wang Y 2014 GATA2 as a potential metastasis-driving gene in prostate cancer. Oncotarget 5 451-461. (doi:10.18632/ oncotarget.1296)

Clegg NJ, Wongvipat J, Joseph JD, Tran C, Ouk S, Dilhas A, Chen Y, Grillot K, Bischoff ED, Cal L, et al. 2012 ARN-509: a novel antiandrogen for prostate cancer treatment. Cancer Research $\mathbf{7 2}$ 1494-1503. (doi:10.1158/0008-5472.CAN-11-3948)

Culig Z, Hobisch A, Cronauer MV, Cato AC, Hittmair A, Radmayr C, Eberle J, Bartsch G \& Klocker H 1993 Mutant androgen receptor detected in an advanced-stage prostatic carcinoma is activated by adrenal androgens and progesterone. Molecular Endocrinology 7 1541-1550. (doi:10.1210/mend.7.12.8145761)

Culig Z, Hoffmann J, Erdel M, Eder IE, Hobisch A, Hittmair A, Bartsch G, Utermann G, Schneider MR, Parczyk K, et al. 1999 Switch from antagonist to agonist of the androgen receptor bicalutamide is associated with prostate tumour progression in a new model system. British Journal of Cancer 81 242-251. (doi:10.1038/sj.bjc.6690684)

Dalal K, Roshan-Moniri M, Sharma A, Li H, Ban F, Hassona MD, Hsing M, Singh K, LeBlanc E, Dehm S, et al. 2014 Selectively targeting the DNA-binding domain of the androgen receptor as a prospective therapy for prostate cancer. Journal of Biological Chemistry 289 26417-26429. (doi:10.1074/jbc.M114.553818)

de Bono JS, Logothetis CJ, Molina A, Fizazi K, North S, Chu L, Chi KN, Jones RJ, Goodman OB Jr, Saad F, et al. 2011 Abiraterone and increased survival in metastatic prostate cancer. New England Journal of Medicine 364 1995-2005. (doi:10.1056/NEJMoa1014618) 
De Gendt K \& Verhoeven G 2012 Tissue- and cell-specific functions of the androgen receptor revealed through conditional knockout models in mice. Molecular and Cellular Endocrinology 352 13-25. (doi:10.1016/j.mce.2011.08.008)

De Mol E, Fenwick RB, Phang CT, Buzon V, Szulc E, de la Fuente A, Escobedo A, Garcia J, Bertoncini CW, Estebanez-Perpina E, et al. 2016 EPI-001, a compound active against castration-resistant prostate cancer, targets transactivation unit 5 of the androgen receptor. ACS Chemical Biology 11 2499-2505. (doi:10.1021/acschembio.6b00182)

Dehm SM, Schmidt LJ, Heemers HV, Vessella RL \& Tindall DJ 2008 Splicing of a novel androgen receptor exon generates a constitutively active androgen receptor that mediates prostate cancer therapy resistance. Cancer Research 68 5469-5477. (doi:10.1158/0008-5472. CAN-08-0594)

Efstathiou E, Titus M, Wen S, Hoang A, Karlou M, Ashe R, Tu SM, Aparicio A, Troncoso P, Mohler J, et al. 2015 Molecular characterization of enzalutamide-treated bone metastatic castrationresistant prostate cancer. European Urology 67 53-60. (doi:10.1016/j. eururo.2014.05.005)

Elo JP, Kvist L, Leinonen K, Isomaa V, Henttu P, Lukkarinen O \& Vihko P 1995 Mutated human androgen receptor gene detected in a prostatic cancer patient is also activated by estradiol. Journal of Clinical Endocrinology and Metabolism 80 3494-3500. (doi:10.1210/ jcem.80.12.8530589)

Ferlay J, Soerjomataram I, Dikshit R, Eser S, Mathers C, Rebelo M, Parkin DM, Forman D \& Bray F 2015 Cancer incidence and mortality worldwide: sources, methods and major patterns in GLOBOCAN 2012. International Journal of Cancer 136 E359-E386. (doi:10.1002/ijc.29210)

Fizazi K, Massard C, Bono P, Jones R, Kataja V, James N, Garcia JA, Protheroe A, Tammela TL, Elliott T, et al. 2014 Activity and safety of ODM-201 in patients with progressive metastatic castration-resistant prostate cancer (ARADES): an open-label phase 1 dose-escalation and randomised phase 2 dose expansion trial. Lancet Oncology 15 975-985. (doi:10.1016/S1470-2045(14)70240-2)

Foley C \& Mitsiades N 2016 Moving beyond the androgen receptor (AR): targeting AR-interacting proteins to treat prostate cancer. Hormones and Cancer 7 84-103. (doi:10.1007/s12672-015-0239-9)

Fujimoto N, Mizokami A, Harada S \& Matsumoto T 2001 Different expression of androgen receptor coactivators in human prostate. Urology 58 289-294. (doi:10.1016/S0090-4295(01)01117-7)

Gao D, Vela I, Sboner A, Iaquinta PJ, Karthaus WR, Gopalan A, Dowling C, Wanjala JN, Undvall EA, Arora VK, et al. 2014 Organoid cultures derived from patients with advanced prostate cancer. Cell 159 176-187. (doi:10.1016/j.cell.2014.08.016)

Gaddipati JP, McLeod DG, Heidenberg HB, Sesterhenn IA, Finger MJ, Moul JW \& Srivastava S 1994 Frequent detection of codon 877 mutation in the androgen receptor gene in advanced prostate cancers. Cancer Research 54 2861-2864.

Geng C, He B, Xu L, Barbieri CE, Eedunuri VK, Chew SA, Zimmermann M, Bond R, Shou J, Li C, et al. 2013 Prostate cancerassociated mutations in speckle-type $\mathrm{POZ}$ protein (SPOP) regulate steroid receptor coactivator 3 protein turnover. PNAS 110 6997-7002. (doi:10.1073/pnas.1304502110)

Geng C, Rajapakshe K, Shah SS, Shou J, Eedunuri VK, Foley C, Fiskus W, Rajendran M, Chew SA, Zimmermann M, et al. 2014 Androgen receptor is the key transcriptional mediator of the tumor suppressor SPOP in prostate cancer. Cancer Research 74 5631-5643. (doi:10.1158/0008-5472.CAN-14-0476)

Gerhardt J, Montani M, Wild P, Beer M, Huber F, Hermanns T, Muntener M \& Kristiansen G 2012 FOXA1 promotes tumor progression in prostate cancer and represents a novel hallmark of castration-resistant prostate cancer. American Journal of Pathology 180 848-861. (doi:10.1016/j.ajpath.2011.10.021)

Gillis JL, Selth LA, Centenera MM, Townley SL, Sun S, Plymate SR, Tilley WD \& Butler LM 2013 Constitutively-active androgen receptor variants function independently of the HSP90 chaperone but do not confer resistance to HSP90 inhibitors. Oncotarget 4 691-704. (doi:10.18632/oncotarget.975)

Grasso CS, Wu YM, Robinson DR, Cao X, Dhanasekaran SM, Khan AP, Quist MJ, Jing X, Lonigro RJ, Brenner JC, et al. 2012 The mutational landscape of lethal castration-resistant prostate cancer. Nature $\mathbf{4 8 7}$ 239-243. (doi:10.1038/nature11125)

Gregory CW, He B, Johnson RT, Ford OH, Mohler JL, French FS \& Wilson EM 2001 A mechanism for androgen receptor-mediated prostate cancer recurrence after androgen deprivation therapy. Cancer Research 61 4315-4319.

Gundem G, Van Loo P, Kremeyer B, Alexandrov LB, Tubio JM, Papaemmanuil E, Brewer DS, Kallio HM, Hognas G, Annala M, et al. 2015 The evolutionary history of lethal metastatic prostate cancer. Nature 520 353-357. (doi:10.1038/nature14347)

Guo Z, Yang X, Sun F, Jiang R, Linn DE, Chen H, Chen H, Kong X, Melamed J, Tepper CG, et al. 2009 A novel androgen receptor splice variant is up-regulated during prostate cancer progression and promotes androgen depletion-resistant growth. Cancer Research 69 2305-2313. (doi:10.1158/0008-5472.CAN-08-3795)

Gustafson JL, Neklesa TK, Cox CS, Roth AG, Buckley DL, Tae HS, Sundberg TB, Stagg DB, Hines J, McDonnell DP, et al. 2015 Smallmolecule-mediated degradation of the androgen receptor through hydrophobic tagging. Angewandte Chemie 54 9659-9662. (doi:10.1002/anie.201503720)

Hara T, Miyazaki J, Araki H, Yamaoka M, Kanzaki N, Kusaka M \& Miyamoto M 2003 Novel mutations of androgen receptor: a possible mechanism of bicalutamide withdrawal syndrome. Cancer Research 63 149-153.

He B, Lanz RB, Fiskus W, Geng C, Yi P, Hartig SM, Rajapakshe K, Shou J, Wei L, Shah SS, et al. 2014 GATA2 facilitates steroid receptor coactivator recruitment to the androgen receptor complex. PNAS 111 18261-18266. (doi:10.1073/pnas.1421415111)

Hickey TE, Robinson JL, Carroll JS \& Tilley WD 2012 Minireview: the androgen receptor in breast tissues: growth inhibitor, tumor suppressor, oncogene? Molecular Endocrinology 26 1252-1267. (doi:10.1210/me.2012-1107)

Hickey TE, Irvine CM, Dvinge H, Tarulli GA, Hanson AR, Ryan NK, Pickering MA, Birrell SN, Hu DG, Mackenzie PI, et al. 2015 Expression of androgen receptor splice variants in clinical breast cancers. Oncotarget 6 44728-44744. (doi:10.18632/oncotarget.6296)

Hornberg E, Ylitalo EB, Crnalic S, Antti H, Stattin P, Widmark A, Bergh A \& Wikstrom P 2011 Expression of androgen receptor splice variants in prostate cancer bone metastases is associated with castration-resistance and short survival. PLOS ONE 6 e19059. (doi:10.1371/journal.pone.0019059)

Hsu AP, McReynolds LJ \& Holland SM 2015 GATA2 deficiency. Current Opinion in Allergy and Clinical Immunology 15 104-109. (doi:10.1097/ ACI.0000000000000126)

Hu R, Dunn TA, Wei S, Isharwal S, Veltri RW, Humphreys E, Han M, Partin AW, Vessella RL, Isaacs WB, et al. 2009 Ligand-independent androgen receptor variants derived from splicing of cryptic exons signify hormone-refractory prostate cancer. Cancer Research 69 16-22. (doi:10.1158/0008-5472.CAN-08-2764)

Hu R, Lu C, Mostaghel EA, Yegnasubramanian S, Gurel M, Tannahill C, Edwards J, Isaacs WB, Nelson PS, Bluemn E, et al. 2012 Distinct transcriptional programs mediated by the ligand-dependent fulllength androgen receptor and its splice variants in castrationresistant prostate cancer. Cancer Research 72 3457-3462. (doi:10.1158/0008-5472.CAN-11-3892)

Jain RK, Mehta RJ, Nakshatri H, Idrees MT \& Badve SS 2011 High-level expression of forkhead-box protein A1 in metastatic prostate cancer. Histopathology 58 766-772. (doi:10.1111/j.13652559.2011.03796.x)

Jiang Y, Palma JF, Agus DB, Wang Y \& Gross ME 2010 Detection of androgen receptor mutations in circulating tumor cells in castration-

Published by Bioscientifica Ltd. 
resistant prostate cancer. Clinical Chemistry 56 1492-1495. (doi:10.1373/clinchem.2010.143297)

Jin HJ, Zhao JC, Wu L, Kim J \& Yu J 2014 Cooperativity and equilibrium with FOXA1 define the androgen receptor transcriptional program. Nature Communications 5 3972. (doi:10.1038/ncomms4972)

Joseph JD, Lu N, Qian J, Sensintaffar J, Shao G, Brigham D, Moon M, Maneval EC, Chen I, Darimont B, et al. 2013 A clinically relevant androgen receptor mutation confers resistance to second-generation antiandrogens enzalutamide and ARN-509. Cancer Discovery 3 1020-1029. (doi:10.1158/2159-8290.CD-13-0226)

Joshi G, Singh PK, Negi A, Rana A, Singh S \& Kumar R 2015 Growth factors mediated cell signalling in prostate cancer progression: Implications in discovery of anti-prostate cancer agents. ChemicoBiological Interactions 240 120-133. (doi:10.1016/j.cbi.2015.08.009)

Kawata H, Ishikura N, Watanabe M, Nishimoto A, Tsunenari T \& Aoki Y 2010 Prolonged treatment with bicalutamide induces androgen receptor overexpression and androgen hypersensitivity. Prostate 70 745-754. (doi:10.1002/pros.21107)

Koivisto P, Kononen J, Palmberg C, Tammela T, Hyytinen E, Isola J, Trapman J, Cleutjens K, Noordzij A, Visakorpi T, et al. 1997 Androgen receptor gene amplification: a possible molecular mechanism for androgen deprivation therapy failure in prostate cancer. Cancer Research 57 314-319.

Korpal M, Korn JM, Gao X, Rakiec DP, Ruddy DA, Doshi S, Yuan J, Kovats SG, Kim S, Cooke VG, et al. 2013 An F876L mutation in androgen receptor confers genetic and phenotypic resistance to MDV3100 (enzalutamide). Cancer Discovery 3 1030-1043. (doi:10.1158/2159-8290.CD-13-0142)

Kumar A, Coleman I, Morrissey C, Zhang X, True LD, Gulati R, Etzioni R, Bolouri H, Montgomery B, White T, et al. 2016 Substantial interindividual and limited intraindividual genomic diversity among tumors from men with metastatic prostate cancer. Nature Medicine 22 369-378. (doi:10.1038/nm.4053)

Kwegyir-Afful AK, Ramalingam S, Purushottamachar P, Ramamurthy VP \& Njar VC 2015 Galeterone and VNPT55 induce proteasomal degradation of AR/AR-V7, induce significant apoptosis via cytochrome c release and suppress growth of castration-resistant prostate cancer xenografts in vivo. Oncotarget 6 27440-27460. (doi:10.18632/oncotarget.4578)

Lallous N, Volik SV, Awrey S, Leblanc E, Tse R, Murillo J, Singh K, Azad AA, Wyatt AW, LeBihan S, et al. 2016 Functional analysis of androgen receptor mutations that confer anti-androgen resistance identified in circulating cell-free DNA from prostate cancer patients. Genome Biology 17 10. (doi:10.1186/s13059-015-0864-1)

Lee DK \& Chang C 2003 Endocrine mechanisms of disease: expression and degradation of androgen receptor: mechanism and clinical implication. Journal of Clinical Endocrinology and Metabolism $\mathbf{8 8}$ 4043-4054. (doi:10.1210/jc.2003-030261)

Li Y, Chan SC, Brand LJ, Hwang TH, Silverstein KA \& Dehm SM 2013 Androgen receptor splice variants mediate enzalutamide resistance in castration-resistant prostate cancer cell lines. Cancer Research $\mathbf{7 3}$ 483-489. (doi:10.1158/0008-5472.CAN-12-3630)

Li H, Ban F, Dalal K, Leblanc E, Frewin K, Ma D, Adomat H, Rennie PS \& Cherkasov A 2014 Discovery of small-molecule inhibitors selectively targeting the DNA-binding domain of the human androgen receptor. Journal of Medicinal Chemistry 57 6458-6467. (doi:10.1021/ jm500802j)

Lin HK, Wang L, Hu YC, Altuwaijri S \& Chang C 2002 Phosphorylationdependent ubiquitylation and degradation of androgen receptor by Akt require Mdm2 E3 ligase. EMBO Journal 21 4037-4048. (doi:10.1093/emboj/cdf406)

Lin D, Wyatt AW, Xue H, Wang Y, Dong X, Haegert A, Wu R, Brahmbhatt S, Mo F, Jong L, et al. 2014 High fidelity patient-derived xenografts for accelerating prostate cancer discovery and drug development. Cancer Research 74 1272-1283. (doi:10.1158/00085472.CAN-13-2921-T)
Linja MJ, Porkka KP, Kang Z, Savinainen KJ, Janne OA, Tammela TL, Vessella RL, Palvimo JJ \& Visakorpi T 2004 Expression of androgen receptor coregulators in prostate cancer. Clinical Cancer Research 10 1032-1040. (doi:10.1158/1078-0432.CCR-0990-3)

Liu G, Sprenger C, Sun S, Epilepsia KS, Haugk K, Zhang X, Coleman I, Nelson PS \& Plymate S 2013 AR variant ARv567es induces carcinogenesis in a novel transgenic mouse model of prostate cancer. Neoplasia 15 1009-1017. (doi:10.1593/neo.13784)

Liu C, Lou W, Zhu Y, Nadiminty N, Schwartz CT, Evans CP \& Gao AC $2014 a$ Niclosamide inhibits androgen receptor variants expression and overcomes enzalutamide resistance in castration-resistant prostate cancer. Clinical Cancer Research 20 3198-3210. (doi:10.1158/1078-0432.CCR-13-3296)

Liu LL, Xie N, Sun S, Plymate S, Mostaghel E \& Dong X $2014 b$ Mechanisms of the androgen receptor splicing in prostate cancer cells. Oncogene 33 3140-3150. (doi:10.1038/onc.2013.284)

Liu C, Lou W, Armstrong C, Zhu Y, Evans CP \& Gao AC 2015 Niclosamide suppresses cell migration and invasion in enzalutamide resistant prostate cancer cells via Stat3-AR axis inhibition. Prostate $\mathbf{7 5}$ 1341-1353. (doi:10.1002/pros.23015)

Liu X, Ledet E, Li D, Dotiwala A, Steinberger A, Feibus A, Li J, Qi Y, Silberstein J, Lee B, et al. 2016 A whole blood assay for AR-V7 and ARv567es in prostate cancer patients. Journal of Urology [in press]. (doi:10.1016/j.juro.2016.06.095)

Lu J, Lonergan PE, Nacusi LP, Wang L, Schmidt LJ, Sun Z, Van der Steen T, Boorjian SA, Kosari F, Vasmatzis G, et al. 2015 The cistrome and gene signature of androgen receptor splice variants in castration resistant prostate cancer cells. Journal of Urology 193 690-698. (doi:10.1016/j.juro.2014.08.043)

Marcelli M, Ittmann M, Mariani S, Sutherland R, Nigam R, Murthy L, Zhao Y, DiConcini D, Puxeddu E, Esen A, et al. 2000 Androgen receptor mutations in prostate cancer. Cancer Research 60 944-949.

Martin SK, Banuelos CA, Sadar MD \& Kyprianou N 2015 N-terminal targeting of androgen receptor variant enhances response of castration resistant prostate cancer to taxane chemotherapy. Molecular Oncology 9 628-639.

McGrath MJ, Binge LC, Sriratana A, Wang H, Robinson PA, Pook D, Fedele CG, Brown S, Dyson JM, Cottle DL, et al. 2013 Regulation of the transcriptional coactivator FHL2 licenses activation of the androgen receptor in castrate-resistant prostate cancer. Cancer Research 73 5066-5079. (doi:10.1158/0008-5472.CAN-12-4520)

Mestayer C, Blanchere M, Jaubert F, Dufour B \& Mowszowicz I 2003 Expression of androgen receptor coactivators in normal and cancer prostate tissues and cultured cell lines. Prostate 56 192-200. (doi:10.1002/pros.10229)

Mohamad NV, Soelaiman IN \& Chin KY 2016 A concise review of testosterone and bone health. Clinical Interventions in Aging 11 1317-1324. (doi:10.2147/CIA.S115472)

Moilanen AM, Riikonen R, Oksala R, Ravanti L, Aho E, Wohlfahrt G, Nykanen PS, Tormakangas OP, Palvimo JJ \& Kallio PJ 2015 Discovery of ODM-201, a new-generation androgen receptor inhibitor targeting resistance mechanisms to androgen signalingdirected prostate cancer therapies. Scientific Reports 512007. (doi:10.1038/srep12007)

Myung JK, Banuelos CA, Fernandez JG, Mawji NR, Wang J, Tien AH, Yang YC, Tavakoli I, Haile S, Watt K, et al. 2013 An androgen receptor N-terminal domain antagonist for treating prostate cancer. Journal of Clinical Investigation 123 2948-2960. (doi:10.1172/ JCI66398)

Nakka M, Agoulnik IU \& Weigel NL 2013 Targeted disruption of the p160 coactivator interface of androgen receptor (AR) selectively inhibits AR activity in both androgen-dependent and castrationresistant AR-expressing prostate cancer cells. International Journal of Biochemistry and Cell Biology 45 763-772. (doi:10.1016/j. biocel.2012.12.012) 
Nakshatri H \& Badve S 2007 FOXA1 as a therapeutic target for breast cancer. Expert Opinion on Therapeutic Targets 11 507-514. (doi:10.1517/14728222.11.4.507)

Nazareth LV, Stenoien DL, Bingman WE 3rd, James AJ, Wu C, Zhang Y, Edwards DP, Mancini M, Marcelli M, Lamb DJ, et al. 1999 A C619Y mutation in the human androgen receptor causes inactivation and mislocalization of the receptor with concomitant sequestration of SRC-1 (steroid receptor coactivator 1). Molecular Endocrinology 13 2065-2075. (doi:10.1210/mend.13.12.0382)

Nead KT, Gaskin G, Chester C, Swisher-McClure S, Leeper NJ \& Shah NH 2016 Association between androgen deprivation therapy and risk of dementia. JAMA Oncology [in press]. (doi:10.1001/ jamaoncol.2016.3662)

Newmark JR, Hardy DO, Tonb DC, Carter BS, Epstein JI, Isaacs WB, Brown TR \& Barrack ER 1992 Androgen receptor gene mutations in human prostate cancer. PNAS 89 6319-6323.

Njar VC \& Brodie AM 2015 Discovery and development of Galeterone (TOK-001 or VN/124-1) for the treatment of all stages of prostate cancer. Journal of Medicinal Chemistry 58 2077-2087. (doi:10.1021/ jm501239f)

Nyquist MD, Li Y, Hwang TH, Manlove LS, Vessella RL, Silverstein KA, Voytas DF \& Dehm SM 2013 TALEN-engineered AR gene rearrangements reveal endocrine uncoupling of androgen receptor in prostate cancer. PNAS 110 17492-17497. (doi:10.1073/ pnas.1308587110)

O’Neill D, Jones D, Wade M, Grey J, Nakjang S, Guo W, Cork D, Davies BR, Wedge SR, Robson CN, et al. 2015 Development and exploitation of a novel mutant androgen receptor modelling strategy to identify new targets for advanced prostate cancer therapy. Oncotarget 6 26029-26040. (doi:10.18632/oncotarget.4347)

Onstenk W, Sieuwerts AM, Kraan J, Van M, Nieuweboer AJ, Mathijssen RH, Hamberg P, Meulenbeld HJ, De Laere B, Dirix LY, et al. 2015 Efficacy of cabazitaxel in castration-resistant prostate cancer is independent of the presence of AR-V7 in circulating tumor cells. European Urology 68 939-945. (doi:10.1016/j.eururo. 2015.07.007)

Pagliarini R, Shao W \& Sellers WR 2015 Oncogene addiction: pathways of therapeutic response, resistance, and road maps toward a cure. EMBO Reports 16 280-296. (doi:10.15252/embr.201439949)

Penning TM 2014 Androgen biosynthesis in castration-resistant prostate cancer. Endocrine-Related Cancer 21 T67-T78. (doi:10.1530/ERC-140109)

Qi J, Tripathi M, Mishra R, Sahgal N, Fazli L, Ettinger S, Placzek WJ, Claps G, Chung LW, Bowtell D, et al. 2013 The E3 ubiquitin ligase Siah2 contributes to castration-resistant prostate cancer by regulation of androgen receptor transcriptional activity. Cancer Cell 23 332-346. (doi:10.1016/j.ccr.2013.02.016)

Qin J, Lee HJ, Wu SP, Lin SC, Lanz RB, Creighton CJ, DeMayo FJ, Tsai SY \& Tsai MJ 2014 Androgen deprivation-induced NCoA2 promotes metastatic and castration-resistant prostate cancer. Journal of Clinical Investigation 124 5013-5026. (doi:10.1172/JCI76412)

Raina K, Lu J, Qian Y, Altieri M, Gordon D, Rossi AM, Wang J, Chen X, Dong H, Siu K, et al. 2016 PROTAC-induced BET protein degradation as a therapy for castration-resistant prostate cancer. PNAS $\mathbf{1 1 3}$ 7124-7129. (doi:10.1073/pnas.1521738113)

Ravindranathan P, Lee TK, Yang L, Centenera MM, Butler L, Tilley WD, Hsieh JT, Ahn JM \& Raj GV 2013 Peptidomimetic targeting of critical androgen receptor-coregulator interactions in prostate cancer. Nature Communications 4 1923. (doi:10.1038/ncomms2912)

Robinson JL, Hickey TE, Warren AY, Vowler SL, Carroll T, Lamb AD, Papoutsoglou N, Neal DE, Tilley WD \& Carroll JS 2014 Elevated levels of FOXA1 facilitate androgen receptor chromatin binding resulting in a CRPC-like phenotype. Oncogene 33 5666-5674. (doi:10.1038/onc.2013.508)

Robinson D, Van Allen EM, Wu YM, Schultz N, Lonigro RJ, Mosquera JM, Montgomery B, Taplin ME, Pritchard CC, Attard G, et al. 2015 Integrative clinical genomics of advanced prostate cancer. Cell 161 1215-1228. (doi:10.1016/j.cell.2015.05.001)

Ryan CJ, Smith MR, de Bono JS, Molina A, Logothetis CJ, de Souza P, Fizazi K, Mainwaring P, Piulats JM, Ng S, et al. 2013 Abiraterone in metastatic prostate cancer without previous chemotherapy. New England Journal of Medicine 368 138-148. (doi:10.1056/ NEJMoa1209096)

Sahu B, Laakso M, Ovaska K, Mirtti T, Lundin J, Rannikko A, Sankila A, Turunen JP, Lundin M, Konsti J, et al. 2011 Dual role of FoxA1 in androgen receptor binding to chromatin, androgen signalling and prostate cancer. EMBO Journal 30 3962-3976. (doi:10.1038/ emboj.2011.328)

Sanchez D, Rosell D, Honorato B, Lopez J, Arocena J \& Sanz G 2006 Androgen receptor mutations are associated with Gleason score in localized prostate cancer. BJU International 98 1320-1325. (doi:10.1111/j.1464-410X.2006.06438.x)

Sarkar S, Brautigan DL, Parsons SJ \& Larner JM 2014 Androgen receptor degradation by the E3 ligase CHIP modulates mitotic arrest in prostate cancer cells. Oncogene 33 26-33. (doi:10.1038/ onc.2012.561)

Scher HI, Buchanan G, Gerald W, Butler LM \& Tilley WD 2004 Targeting the androgen receptor: improving outcomes for castration-resistant prostate cancer. Endocrine-Related Cancer 11 459-476. (doi:10.1677/ erc.1.00525)

Scher HI, Fizazi K, Saad F, Taplin ME, Sternberg CN, Miller K, de Wit R, Mulders P, Chi KN, Shore ND, et al. 2012 Increased survival with enzalutamide in prostate cancer after chemotherapy. New England Journal of Medicine 367 1187-1197. (doi:10.1056/NEJMoa1207506)

Scher HI, Lu D, Schreiber NA, Louw J, Graf RP, Vargas HA, Johnson A, Jendrisak A, Bambury R, Danila D, et al. 2016 Association of AR-V7 on circulating tumor cells as a treatment-specific biomarker with outcomes and survival in castration-resistant prostate cancer. JAMA Oncology 196 1124. (doi:10.1016/j.juro.2016.07.066)

Schweizer MT, Antonarakis ES, Wang H, Ajiboye AS, Spitz A, Cao H, Luo J, Haffner MC, Yegnasubramanian S, Carducci MA, et al. 2015 Effect of bipolar androgen therapy for asymptomatic men with castration-resistant prostate cancer: results from a pilot clinical study. Science Translational Medicine 7 269ra262. (doi:10.1126/ scitranslmed.3010563)

Seo WY, Jeong BC, Yu EJ, Kim HJ, Kim SH, Lim JE, Kwon GY, Lee HM \& Kim JH 2013 CCAR1 promotes chromatin loading of androgen receptor (AR) transcription complex by stabilizing the association between AR and GATA2. Nucleic Acids Research 41 8526-8536. (doi:10.1093/nar/gkt644)

Sequist LV, Waltman BA, Dias-Santagata D, Digumarthy S, Turke AB, Fidias P, Bergethon K, Shaw AT, Gettinger S, Cosper AK, et al. 2011 Genotypic and histological evolution of lung cancers acquiring resistance to EGFR inhibitors. Science Translational Medicine 3 75ra26. (doi:10.1126/scitranslmed.3002003)

Shi XB, Ma AH, Xue L, Li M, Nguyen HG, Yang JC, Tepper CG, Gandour-Edwards R, Evans CP, Kung HJ, et al. 2015 miR-124 and androgen receptor signaling inhibitors repress prostate cancer growth by downregulating androgen receptor splice variants, EZH2, and Src. Cancer Research 75 5309-5317. (doi:10.1158/0008-5472. CAN-14-0795)

Siegel RL, Miller KD \& Jemal A 2016 Cancer statistics, 2016. CA: A Cancer Journal for Clinicians 66 7-30. (doi:10.3322/caac.21332)

Small EJ, Halabi S, Dawson NA, Stadler WM, Rini BI, Picus J, Gable P, Torti FM, Kaplan E \& Vogelzang NJ 2004 Antiandrogen withdrawal alone or in combination with ketoconazole in androgenindependent prostate cancer patients: a phase III trial (CALGB 9583). Journal of Clinical Oncology 22 1025-1033. (doi:10.1200/ JCO.2004.06.037)

Spratt DE, Evans MJ, Davis BJ, Doran MG, Lee MX, Shah N, Wongvipat J, Carnazza KE, Klee GG, Polkinghorn W, et al. 2015 Androgen receptor upregulation mediates radioresistance after 
ionizing radiation. Cancer Research 75 4688-4696. (doi:10.1158/00085472.CAN-15-0892)

Steinkamp MP, O’Mahony OA, Brogley M, Rehman H, Lapensee EW Dhanasekaran S, Hofer MD, Kuefer R, Chinnaiyan A, Rubin MA, et al. 2009 Treatment-dependent androgen receptor mutations in prostate cancer exploit multiple mechanisms to evade therapy. Cancer Research 69 4434-4442. (doi:10.1158/0008-5472.CAN-083605)

Steketee K, Timmerman L, Ziel-van der Made AC, Doesburg P, Brinkmann AO \& Trapman J 2002 Broadened ligand responsiveness of androgen receptor mutants obtained by random amino acid substitution of H874 and mutation hot spot T877 in prostate cancer. International Journal of Cancer 100 309-317. (doi:10.1002/ijc.10495)

Stockley J, Markert E, Zhou Y, Robson CN, Elliott DJ, Lindberg J, Leung HY \& Rajan P 2015 The RNA-binding protein Sam68 regulates expression and transcription function of the androgen receptor splice variant AR-V7. Scientific Reports 5 13426. (doi:10.1038/ srep13426)

Sun S, Sprenger CC, Vessella RL, Haugk K, Soriano K, Mostaghel EA, Page ST, Coleman IM, Nguyen HM, Sun H, et al. 2010 Castration resistance in human prostate cancer is conferred by a frequently occurring androgen receptor splice variant. Journal of Clinical Investigation 120 2715-2730. (doi:10.1172/JCI41824)

Suzuki H, Sato N, Watabe Y, Masai M, Seino S \& Shimazaki J 1993 Androgen receptor gene mutations in human prostate cancer. Journal of Steroid Biochemistry and Molecular Biology 46 759-765. (doi:10.1016/0960-0760(93)90316-O)

Suzuki H, Akakura K, Komiya A, Aida S, Akimoto S \& Shimazaki J 1996 Codon 877 mutation in the androgen receptor gene in advanced prostate cancer: relation to antiandrogen withdrawal syndrome. Prostate 29 153-158. (doi:10.1002/10970045(199609)29:3<153::AID-PROS2990290303>3.0.CO;2-5)

Tan J, Sharief Y, Hamil KG, Gregory CW, Zang DY, Sar M, Gumerlock PH, deVere White RW, Pretlow TG, Harris SE, et al. 1997 Dehydroepiandrosterone activates mutant androgen receptors expressed in the androgen-dependent human prostate cancer xenograft CWR22 and LNCaP cells. Molecular Endocrinology 11 450-459. (doi:10.1210/mend.11.4.9906)

Tang YQ, Han BM, Yao XQ, Hong Y, Wang Y, Zhao FJ, Yu SQ, Sun XW $\&$ Xia SJ 2009 Chimeric molecules facilitate the degradation of androgen receptors and repress the growth of LNCaP cells. Asian Journal of Andrology 11 119-126. (doi:10.1038/aja.2008.26)

Taplin ME, Bubley GJ, Shuster TD, Frantz ME, Spooner AE, Ogata GK, Keer HN \& Balk SP 1995 Mutation of the androgen-receptor gene in metastatic androgen-independent prostate cancer. New England Journal of Medicine 332 1393-1398. (doi:10.1056/ NEJM199505253322101)

Taplin ME, Bubley GJ, Ko YJ, Small EJ, Upton M, Rajeshkumar B \& Balk SP 1999 Selection for androgen receptor mutations in prostate cancers treated with androgen antagonist. Cancer Research 59 2511-2515.

Taplin ME, Rajeshkumar B, Halabi S, Werner CP, Woda BA, Picus J, Stadler W, Hayes DF, Kantoff PW, Vogelzang NJ, et al. 2003 Androgen receptor mutations in androgen-independent prostate cancer: Cancer and Leukemia Group B Study 9663. Journal of Clinical Oncology 21 2673-2678. (doi:10.1200/JCO.2003.11.102)

Taylor BS, Schultz N, Hieronymus H, Gopalan A, Xiao Y, Carver BS, Arora VK, Kaushik P, Cerami E, Reva B, et al. 2010 Integrative genomic profiling of human prostate cancer. Cancer Cell 18 11-22. (doi:10.1016/j.ccr.2010.05.026)

Thompson J, Hyytinen ER, Haapala K, Rantala I, Helin HJ, Janne OA, Palvimo JJ \& Koivisto PA 2003 Androgen receptor mutations in high-grade prostate cancer before hormonal therapy. Laboratory Investigation 83 1709-1713. (doi:10.1097/01. LAB.0000107262.40402.44)
Thoreson GR, Gayed BA, Chung PH \& Raj GV 2014 Emerging therapies in castration resistant prostate cancer. Canadian Journal of Urology $\mathbf{2 1}$ 98-105.

Tilki D \& Evans CP 2014 The changing landscape of advanced and castration resistant prostate cancer: latest science and revised definitions. Canadian Journal of Urology 21 7-13.

Tilley WD, Buchanan G, Hickey TE \& Bentel JM 1996 Mutations in the androgen receptor gene are associated with progression of human prostate cancer to androgen independence. Clinical Cancer Research 2 277-285.

Todenhofer T, Azad A, Stewart C, Gao J, Eigl BJ, Gleave ME, Joshua AM, Black PC \& Chi KN 2016 AR-V7 transcripts in whole blood RNA of patients with metastatic castration resistant prostate cancer correlate with response to Abiraterone acetate. Journal of Urology [in press]. (doi:10.1016/j.juro.2016.06.094)

Tsai HC, Boucher DL, Martinez A, Tepper CG \& Kung HJ 2012 Modeling truncated AR expression in a natural androgen responsive environment and identification of $\mathrm{RHOB}$ as a direct transcriptional target. PLOS ONE 7 e49887. (doi:10.1371/journal.pone.0049887)

Velders M \& Diel P 2013 How sex hormones promote skeletal muscle regeneration. Sports Medicine 43 1089-1100. (doi:10.1007/s40279. 013-0081-6)

Veldscholte J, Ris-Stalpers C, Kuiper GG, Jenster G, Berrevoets C, Claassen E, van Rooij HC, Trapman J, Brinkmann AO \& Mulder E 1990 A mutation in the ligand binding domain of the androgen receptor of human $\mathrm{LNCaP}$ cells affects steroid binding characteristics and response to anti-androgens. Biochemical and Biophysical Research Communications 173 534-540. (doi:10.1016/ S0006-291X(05)80067-1)

Vidal SJ, Rodriguez-Bravo V, Quinn SA, Rodriguez-Barrueco R, Lujambio A, Williams E, Sun X, de la Iglesia-Vicente J, Lee A, Readhead B, et al. 2015 A targetable GATA2-IGF2 axis confers aggressiveness in lethal prostate cancer. Cancer Cell 27 223-239. (doi:10.1016/j.ccell.2014.11.013)

Visakorpi T, Hyytinen E, Koivisto P, Tanner M, Keinanen R, Palmberg C, Palotie A, Tammela T, Isola J \& Kallioniemi OP 1995 In vivo amplification of the androgen receptor gene and progression of human prostate cancer. Nature Genetics 9 401-406. (doi:10.1038/ ng0495-401)

Voutsadakis IA \& Papandreou CN 2012 The ubiquitin-proteasome system in prostate cancer and its transition to castration resistance. Urologic Oncology 30 752-761. (doi:10.1016/j.urolonc.2010.03.013)

Wallen MJ, Linja M, Kaartinen K, Schleutker J \& Visakorpi T 1999 Androgen receptor gene mutations in hormone-refractory prostate cancer. Journal of Pathology 189 559-563. (doi:10.1002/(SICI)10969896(199912)189:4<559::AID-PATH471>3.0.CO;2-Y)

Wang Q, Li W, Zhang Y, Yuan X, Xu K, Yu J, Chen Z, Beroukhim R, Wang H, Lupien M, et al. 2009 Androgen receptor regulates a distinct transcription program in androgen-independent prostate cancer. Cell 138 245-256. (doi:10.1016/j.cell.2009.04.056)

Wang D, Garcia-Bassets I, Benner C, Li W, Su X, Zhou Y, Qiu J, Liu W, Kaikkonen MU, Ohgi KA, et al. 2011 Reprogramming transcription by distinct classes of enhancers functionally defined by eRNA. Nature 474 390-394. (doi:10.1038/nature10006)

Wang J, Zou JX, Xue X, Cai D, Zhang Y, Duan Z, Xiang Q, Yang JC, Louie MC, Borowsky AD, et al. 2016 ROR-gamma drives androgen receptor expression and represents a therapeutic target in castrationresistant prostate cancer. Nature Medicine 22 488-496. (doi:10.1038/ nm.4070)

Watson PA, Chen YF, Balbas MD, Wongvipat J, Socci ND, Viale A, Kim K \& Sawyers CL 2010 Constitutively active androgen receptor splice variants expressed in castration-resistant prostate cancer require fulllength androgen receptor. PNAS 107 16759-16765. (doi:10.1073/ pnas.1012443107)

Weinstein IB 2002 Cancer. Addiction to oncogenes - the Achilles heal of cancer. Science 297 63-64. (doi:10.1126/science.1073096) 
Welti J, Rodrigues DN, Sharp A, Sun S, Lorente D, Riisnaes R, Figueiredo I, Zafeiriou Z, Rescigno P, de Bono JS, et al. 2016 Analytical validation and clinical qualification of a new immunohistochemical assay for androgen receptor splice variant-7 protein expression in metastatic castration-resistant prostate cancer. European Urology 70 599-608. (doi:10.1016/j.eururo.2016.03.049)

Wyatt AW \& Gleave ME 2015 Targeting the adaptive molecular landscape of castration-resistant prostate cancer. EMBO Molecular Medicine 7 878-894. (doi:10.15252/emmm.201303701)

Wyatt AW, Azad AA, Volik SV, Annala M, Beja K, McConeghy B, Haegert A, Warner EW, Mo F, Brahmbhatt S, et al. 2016 Genomic alterations in cell-free DNA and enzalutamide resistance in castration-resistant prostate cancer. JAMA Oncology [in press] (doi:10.1001/jamaoncol.2016.0494)

Xu J, Wu RC \& O'Malley BW 2009a Normal and cancer-related functions of the p160 steroid receptor co-activator (SRC) family. Nature Reviews Cancer 9 615-630. (doi:10.1038/nrc2695)

Xu K, Shimelis H, Linn DE, Jiang R, Yang X, Sun F, Guo Z, Chen H, $\mathrm{Li} \mathrm{W}$, Chen $\mathrm{H}$, et al. $2009 \mathrm{~b}$ Regulation of androgen receptor transcriptional activity and specificity by RNF6-induced ubiquitination. Cancer Cell 15 270-282. (doi:10.1016/j. ccr.2009.02.021)

Xu D, Zhan Y, Qi Y, Cao B, Bai S, Xu W, Gambhir SS, Lee P, Sartor O, Flemington EK, et al. 2015 Androgen receptor splice variants dimerize to transactivate target genes. Cancer Research 75 3663-3671. (doi:10.1158/0008-5472.CAN-15-0381)

Yamamoto Y, Loriot Y, Beraldi E, Zhang F, Wyatt AW, Nakouzi NA, Mo F, Zhou T, Kim Y, Monia BP, et al. 2015 Generation 2.5 antisense oligonucleotides targeting the androgen receptor and its splice variants suppress enzalutamide-resistant prostate cancer cell growth. Clinical Cancer Research 21 1675-1687. (doi:10.1158/1078-0432.CCR14-1108)

Yang YA \& Yu J 2015 Current perspectives on FOXA1 regulation of androgen receptor signaling and prostate cancer. Genes and Diseases 2 144-151. (doi:10.1016/j.gendis.2015.01.003)

Yang YC, Banuelos CA, Mawji NR, Wang J, Kato M, Haile S, McEwan IJ, Plymate S \& Sadar MD 2016 Targeting androgen receptor activation function-1 with EPI to overcome resistance mechanisms in castration-resistant prostate cancer. Clinical Cancer Research 22 4466-4477. (doi:10.1158/1078-0432.CCR-15-2901)

Yoon HG \& Wong J 2006 The corepressors silencing mediator of retinoid and thyroid hormone receptor and nuclear receptor corepressor are involved in agonist- and antagonist-regulated transcription by androgen receptor. Molecular Endocrinology 20 1048-1060. (doi:10.1210/me.2005-0324)

Yu Z, Cai C, Gao S, Simon NI, Shen HC \& Balk SP 2014a Galeterone prevents androgen receptor binding to chromatin and enhances degradation of mutant androgen receptor. Clinical Cancer Research 20 4075-4085. (doi:10.1158/1078-0432.CCR-14-0292)

Yu Z, Chen S, Sowalsky AG, Voznesensky OS, Mostaghel EA, Nelson PS, Cai C \& Balk SP 2014b Rapid induction of androgen receptor splice variants by androgen deprivation in prostate cancer. Clinical Cancer Research 20 1590-1600. (doi:10.1158/1078-0432.CCR-13-1863)

Zaman N, Giannopoulos PN, Chowdhury S, Bonneil E, Thibault P, Wang E, Trifiro M \& Paliouras M 2014 Proteomic-coupled-network analysis of T877A-androgen receptor interactomes can predict clinical prostate cancer outcomes between White (non-Hispanic) and African-American groups. PLoS ONE 9 e113190. (doi:10.1371/ journal.pone.0113190)

Zhang J, Adrian FJ, Jahnke W, Cowan-Jacob SW, Li AG, Iacob RE, Sim T, Powers J, Dierks C, Sun F, et al. 2010 Targeting Bcr-Abl by combining allosteric with ATP-binding-site inhibitors. Nature 463 501-506. (doi:10.1038/nature08675)

Zhang Y, Castaneda S, Dumble M, Wang M, Mileski M, Qu Z, Kim S, Shi V, Kraft P, Gao Y, et al. 2011 Reduced expression of the androgen receptor by third generation of antisense shows antitumor activity in models of prostate cancer. Molecular Cancer Therapeutics 10 2309-2319. (doi:10.1158/1535-7163.MCT-11-0329)

Zhao XY, Malloy PJ, Krishnan AV, Swami S, Navone NM, Peehl DM \& Feldman D 2000 Glucocorticoids can promote androgenindependent growth of prostate cancer cells through a mutated androgen receptor. Nature Medicine 6 703-706. (doi:10.1038/76287)

Zhao JC, Fong KW, Jin HJ, Yang YA, Kim J \& Yu J 2016 FOXA1 acts upstream of GATA2 and AR in hormonal regulation of gene expression. Oncogene 35 4335-4344. (doi:10.1038/onc.2015.496)

Received in final form 24 October 2016

Accepted 25 October 2016

Accepted Preprint published online 31 October 2016
() 2016 Society for Endocrinology Printed in Great Britain
Published by Bioscientifica Ltd 